c. 2

\title{
1 Corps
}

-. -.....reers

Waterways Experiment

Station

\section{Navigation Study of Proposed Improvements to the Salem River Navigation Channel, New Jersey}

by Larry L. Daggett, Michelle M. Thevenot

Approved For Public Release; Distribution Is Unlimited

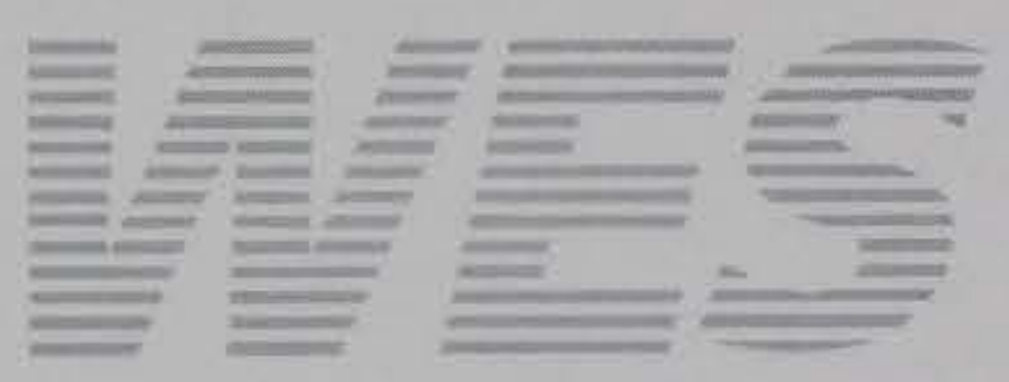




\section{Navigation Study of Proposed Improvements to the Salem River Navigation Channel, New Jersey}

by Larry L. Daggett, Michelle M. Thevenot

U.S. Army Corps of Engineers

Waterways Experiment Station

3909 Halls Ferry Road

Vicksburg, MS 39180-6199

Final report

Approved for Public Release; Distribution is Unlimited

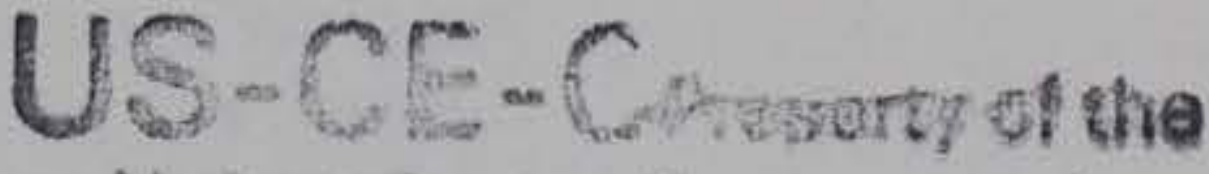

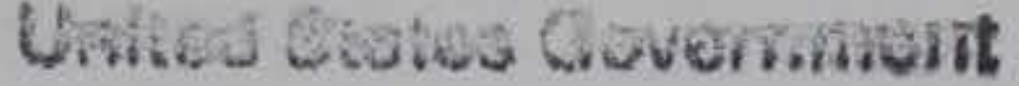

RESEARCH LIBRARY

US ARMY ENCIIEER WATERWAYS

EXPERINE.VT STATION

VICISBURG, MISSISSIPPI

Prepared for U.S. Army Engineer District, Philadelphia Philadelphia, PA 19106-2991 


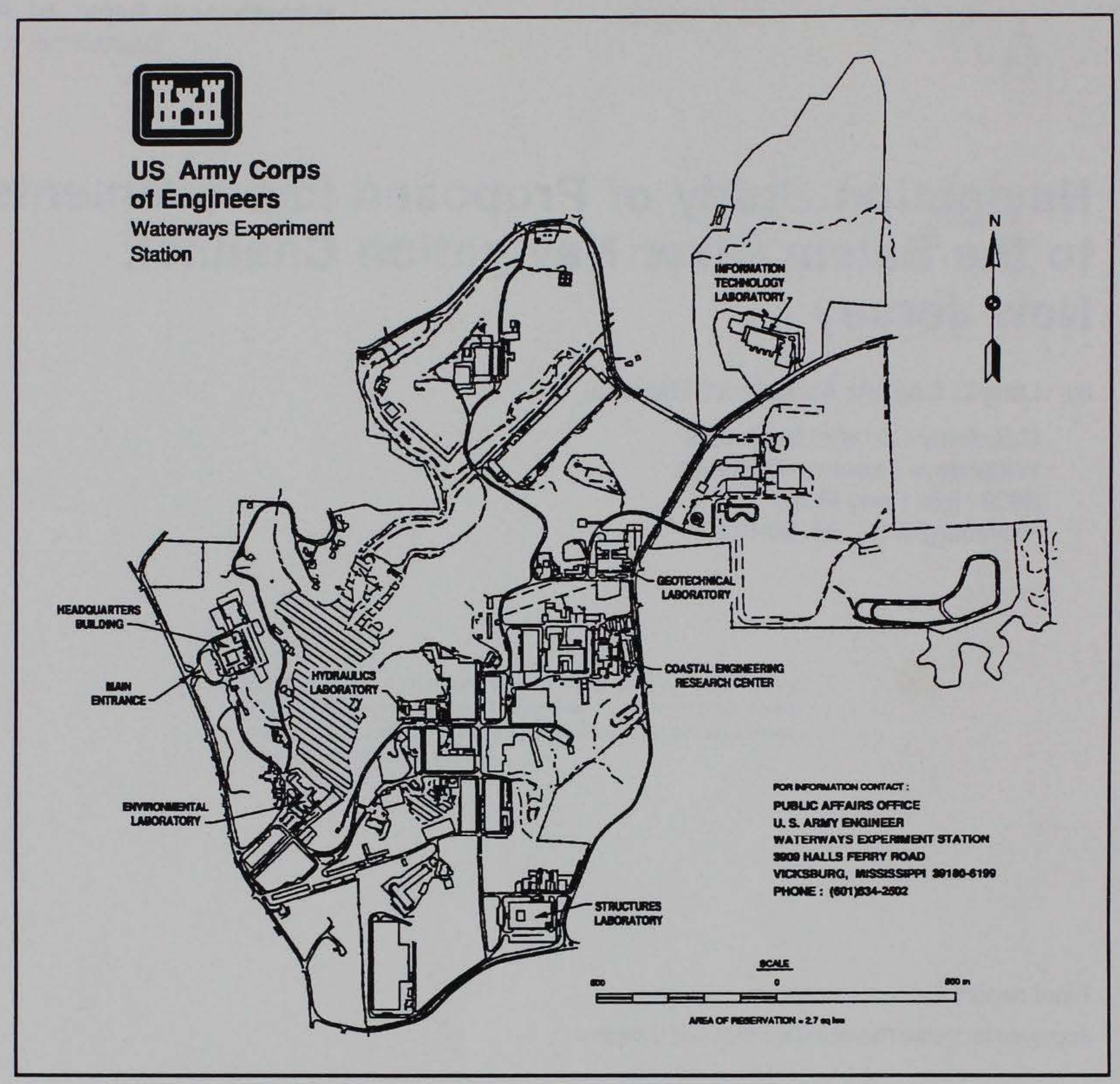

Waterways Experiment Station Cataloging-in-Publication Data

Daggett, Larry L.

Navigation study of proposed improvements to the Salem River

Navigation Channel, New Jersey / by Larry L. Daggett, Michelle M.

Thevenot ; prepared for U.S. Army Engineer District, Philadelphia.

62 p. : ill. ; $28 \mathrm{~cm}$. - (Miscellaneous paper ; HL-95-5)

Includes bibliographic references.

1. Navigation - New Jersey. 2. Salem River (N.J.) - Navigation.

I. Thevenot, Michelle M. II. United States. Army. Corps of Engineers.

Philadelphia District. III. U.S. Army Engineer Waterways Experiment

Station. IV. Hydraulics Laboratory (U.S. Army Engineer Waterways

Experiment Station) V. Title. VI. Series: Miscellaneous paper

(U.S. Army Engineer Waterways Experiment Station) ; HL-95-5.

TA7 W34m no.HL-95-5 


\section{Contents}

Preface $\ldots \ldots \ldots \ldots \ldots \ldots \ldots \ldots \ldots \ldots \ldots \ldots \ldots \ldots \ldots \ldots \ldots \ldots$, iv

Conversion Factors, Non-SI to SI Units of Measurement $\ldots \ldots \ldots \ldots \ldots v$

1 -Introduction $\ldots \ldots \ldots \ldots \ldots \ldots \ldots \ldots \ldots \ldots \ldots \ldots \ldots \ldots \ldots$

Background $\ldots \ldots \ldots \ldots \ldots \ldots \ldots \ldots \ldots \ldots \ldots \ldots \ldots \ldots \ldots \ldots \ldots \ldots$

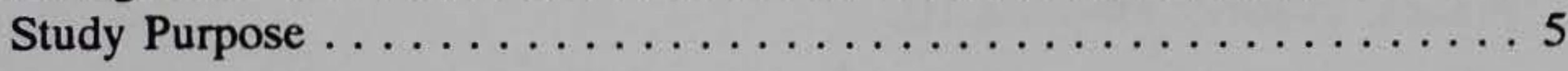

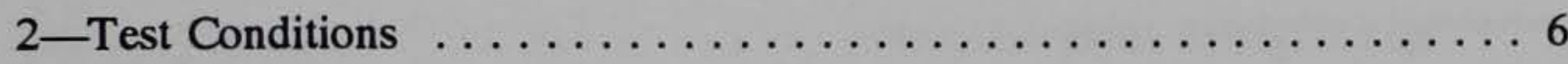

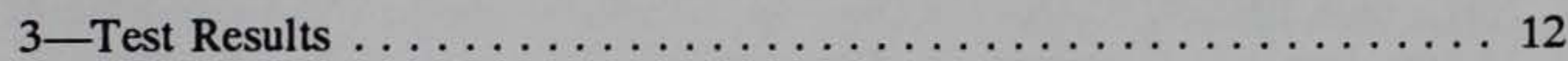

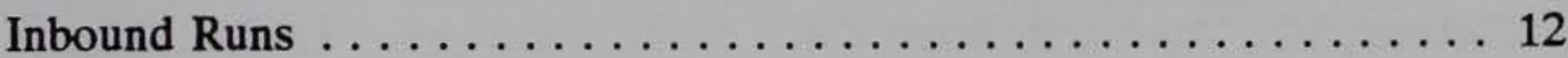

Outbound Runs $\ldots \ldots \ldots \ldots \ldots \ldots \ldots \ldots \ldots \ldots \ldots \ldots \ldots \ldots \ldots \ldots$

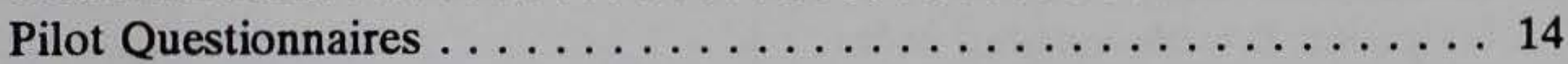

Discussion ............................ 15

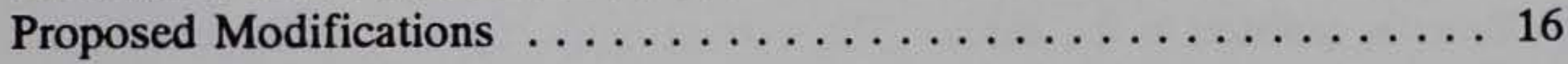

4-Recommendations ......................... 19

Table 1

Plates 1-32

SF 298 


\section{Preface}

This navigation study was performed by the Hydraulics Laboratory (HL) of the U.S. Army Engineer Waterways Experiment Station (WES) for the U.S. Army Engineer District, Philadelphia. Simulator testing performed with the Salem River pilots was conducted with the WES ship/tow simulator ending February 1992 . Current modeling was conducted by the Estuarine Simulation Branch, Estuaries Division, HL.

The navigation study was performed by Ms. Michelle $M$. Thevenot of the Navigation Branch, Waterways Division, HL, under the general supervision of Messrs. Frank A. Herrmann, Jr., Director, HL; Richard A. Sager, Assistant Director, HL; Marden B. Boyd, Chief of the Waterways Division; and Dr. Larry L. Daggett, Chief of the Navigation Branch. Mr. Gary Lynch, Navigation Branch, assisted in the field investigation at the beginning of the study, and Ms. Donna Derrick, Civil Engineering Technician, Navigation Branch, assisted in the study. The current modeling study was performed by Ms. Barbara P. Donnell, Estuarine Simulation Branch. This report was prepared by Ms. Thevenot and Dr. Daggett.

Acknowledgement is made to Messers. George A. Sauls and Jeff Gebert, Hydrology-Hydraulics Branch of the Philadelphia District, for their cooperation and assistance throughout the investigation. Special thanks go to the Salem River pilots who participated in the testing program and provided their valuable insight into the project study.

During the preparation of this report, Director of WES was Dr. Robert W. Whalin. Commander was COL Bruce K. Howard, EN. 


\section{Conversion Factors, Non-SI to SI Units of Measurement}

Non-SI units of measurement used in this report can be converted to SI units as follows:

\begin{tabular}{||l|l|l||}
\hline Multiply & By & To Obtain \\
\hline \hline cubic feet & 0.02831685 & cubic meters \\
\hline degrees (angle) & 0.01745329 & radians \\
\hline feet & 0.3048 & meters \\
\hline $\begin{array}{l}\text { horsepower (550 foot-pounds } \\
\text { (force) per second) }\end{array}$ & 745.6999 & watts \\
\hline knots (international) & 0.5144444 & meters per second \\
\hline miles (U.S. statute) & 1.609347 & kilometers \\
\hline
\end{tabular}




\section{Introduction}

\section{Background}

The Salem River study addresses an area in Salem County, New Jersey, surrounding the Salem River, a tidal stream entering the Delaware River at mile 60, about 45 miles $^{1}$ south of Philadelphia, PA (Figure 1). The present Salem River project provides an entrance channel from Delaware Bay to the fixed Route 49 highway bridge, Penns Neck Bridge, in Salem, a distance of about 5 miles. The existing authorized depth is $12 \mathrm{ft}$ mean low water (mlw) with a width of $150 \mathrm{ft}$ from the Delaware River through Salem Cove, narrowing to $100 \mathrm{ft}$ at the cutoff at Sinnicksons Landing. The existing Salem River channel is shown in Figure 2. Since the 1984 maintenance dredging to authorized dimensions, the most common size ship using the river is a 50 - by 270 - $\mathrm{ft}$ general cargo vessel with a $14.5-\mathrm{ft}$ draft and 5,000 deadweight tonnage (dwt). The longest ship taken up the river was $347 \mathrm{ft}$ long with a beam of $60 \mathrm{ft}$. The widest vessel to use the port was 65 by $310 \mathrm{ft}$. The recommended draft restriction was adjusted by the pilots to $15.5 \mathrm{ft}$ when maintenance dredging was completed in July 1988. Safe underkeel clearance is considered to be $2 \mathrm{ft}$.

Traffic is one way, and all vessels arriving at or departing from the port must be tug-assisted. According to the pilots, vessels currently transiting the river use the tide (range 5-6 ft) for efficient operation. Ships using the channel at high tide have approximately $17 \mathrm{ft}$ of depth with which to work. Since normal transit time is about 45 minutes, when the tide is high enough for the vessels requiring a $17-\mathrm{ft}$ channel, the high tide window permits two vessels to move through the channel. General cargo and bulk vessels are navigated by Delaware River pilots to the Reedy Point Anchorage. Contract Salem River pilots take ships from Reedy Point to the Salem Port, turn, and dock the ships port-side-to. Three licensed pilots are available; all three pilots participated in this study's tests.

Vessels normally encounter a 6- to 7-knot current and are subjected to wind forces that necessitate tug assistance. A 525 -hp tug presently provides tug service on the Salem River. Vessels over $330 \mathrm{ft}$ in length or moving during

\footnotetext{
1 A table of factors for converting non-SI units of measurement to SI units is found on page v.
} 


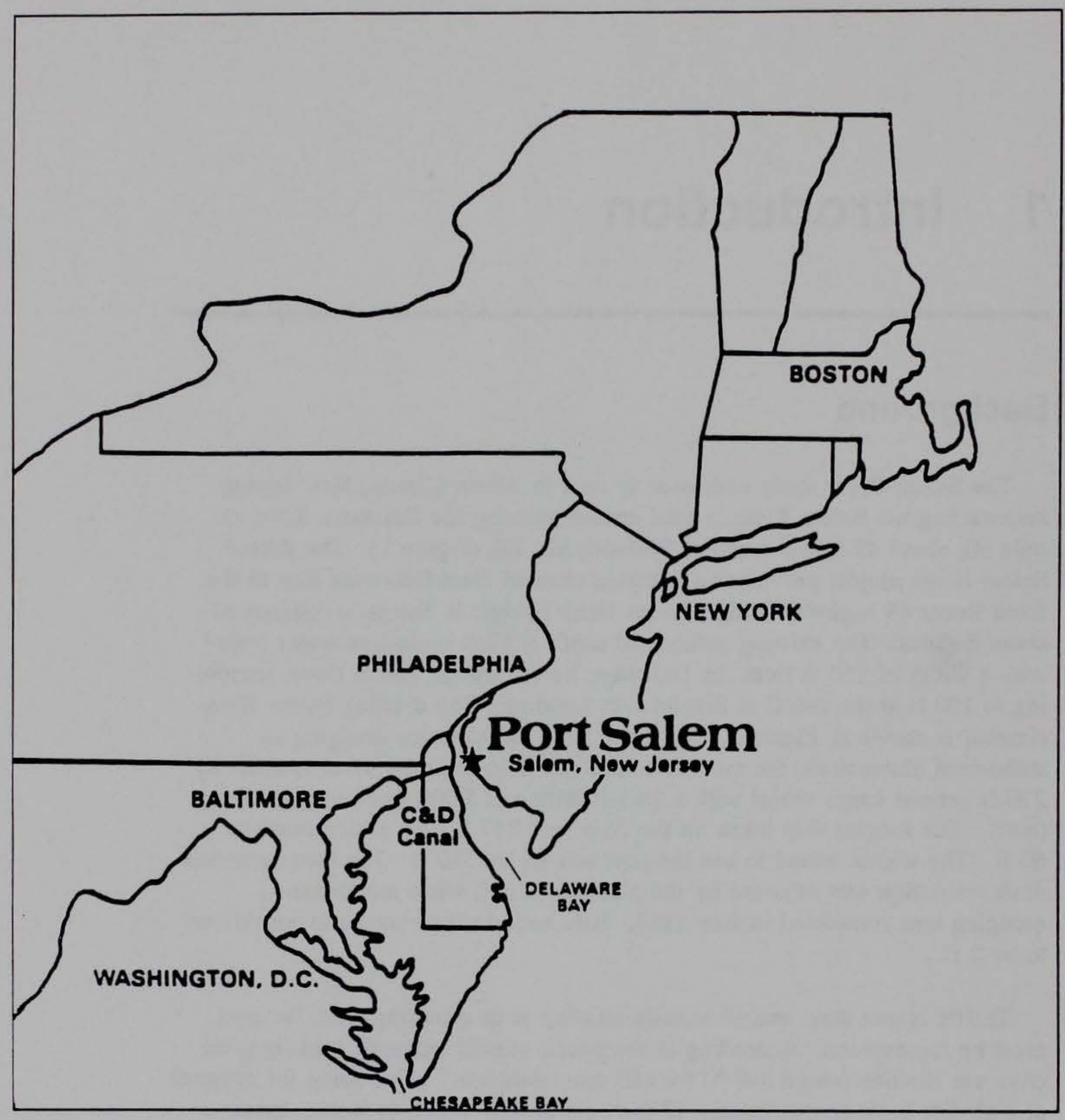

Figure 1. Study area

adverse weather conditions sometimes require the use of two tugs or a larger tug $(1,100 \mathrm{hp})$ unless the vessel has thrusters to enhance maneuverability.

As noted previously, vessel transits on the Salem River are normally made on flood tide depending on the draft requirement of the vessel. To allow for turning and maneuvering during favorable current conditions, transits are timed to arrive at the port area near slack water on the flood tide. Presently, there is no designated maneuvering area; however, the deep water located between Penns Neck Bridge and the old Salem River channel near the Mid-Atlantic Shipping Terminal (Figure 3) is used for this purpose. When turning, the tug 


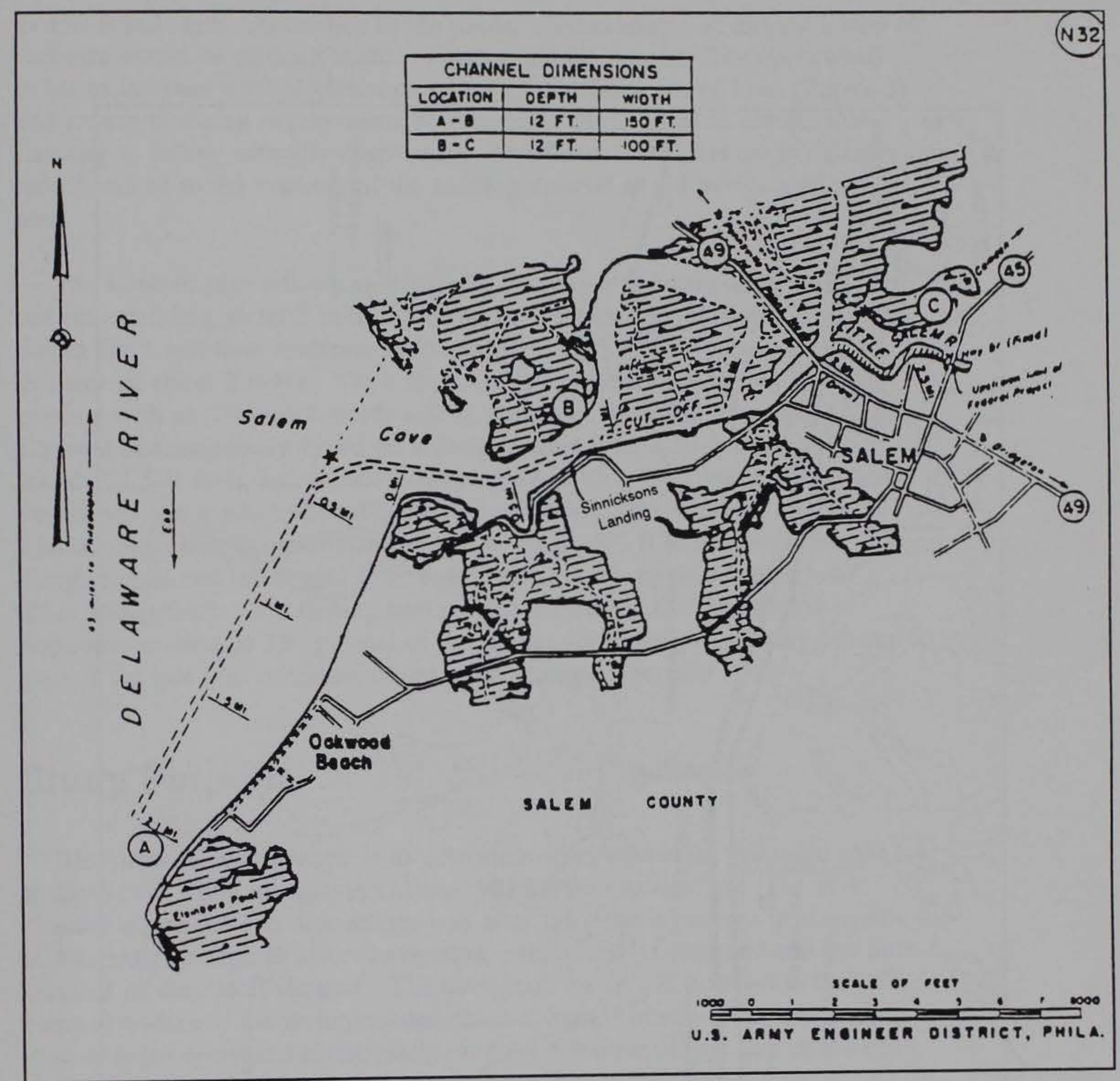

Figure 2. Existing project

is positioned on the starboard bow perpendicular to the keel to rotate the ship to the left 180 degrees until it is facing downstream.

The U.S. Coast Guard has improved the navigation aids on the Salem River since the 1984 maintenance dredging. Two lights and twelve lighted navigation aids were added in 1989 to improve the system.

Channel dimensions, both width and depth, present problems at Salem River. The primary problem area for maneuvering is the bend in Salem Cove where the channel turns southward toward the Delaware Bay. Difficult hydraulic conditions and shoaling in this area result in frequent minor groundings. However, no extensive damage has been reported as a result of groundings. The Port of Salem has considered the possibility of docking ships up 


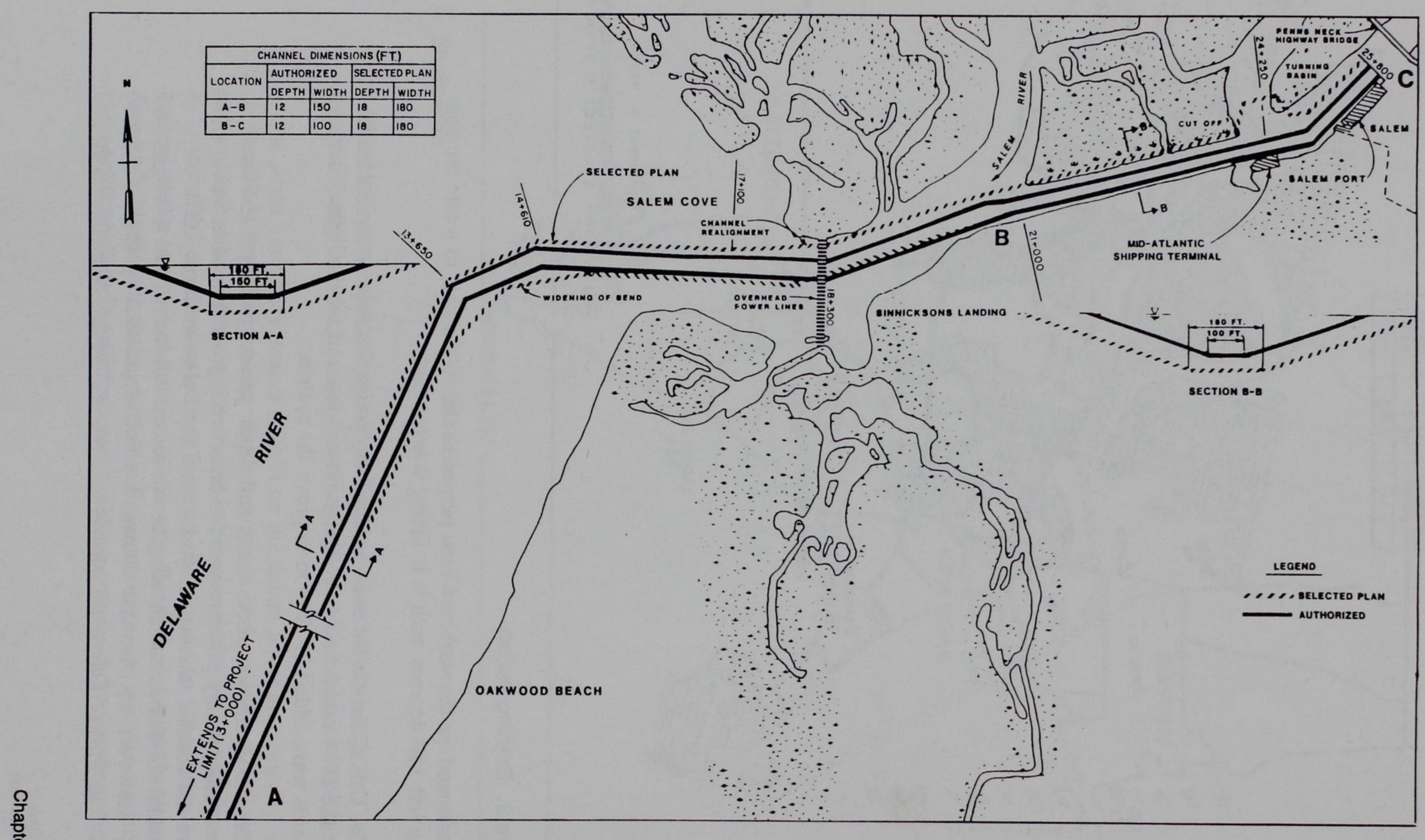

Figure 3. Selected plan 
to $450 \mathrm{ft}$ in length. According to the pilots, maneuvering and turning a ship of that size would be difficult without channel improvements. The opportunity exists to increase vertical clearance under the overhead power lines (Figure 3) and reduce dredging requirements by realigning the channel at Sinnicksons Landing to follow naturally deep water. The Coast Guard has made extensive modifications to the marking of the existing channel to aid navigation in this area.

The selected plan (shown in Figure 3) consists of a 5-mile-long navigation project extending about 3 miles up from the Delaware River main channel to Salem Cove and then upstream to Penns Neck Highway Bridge at Route 49, a distance of about 2 miles. The selected plan provides for a $180-\mathrm{ft}$, one-way channel with an 18-ft-mlw depth and an allowable dredging overdepth of $2 \mathrm{ft}$. Channel dimensions are based on a design vessel with a $50-\mathrm{ft}$ beam, $330-\mathrm{ft}$ length, $21.5-\mathrm{ft}$ draft, and an accompanying tug with a $10-\mathrm{ft}$ beam. This draft vessel will use a 5.5 - $\mathrm{ft}$ tide with the recommended $2-\mathrm{ft}$ underkeel clearance. The turning basin dimensions provide a width of $495 \mathrm{ft}$ to accommodate the design vessel and the largest anticipated vessel, a 65 - by $350-\mathrm{ft}$ ship with a 27-ft design draft. The turning basin width satisfies U.S. Army Corps of Engineers criteria of 150 percent of the design vessel length. Taking advantage of the tide will continue to maximize economic benefits.

\section{Study Purpose}

The purpose of this study is to determine what effects the proposed changes to the Salem River navigation channel will have on navigation. The new channel alignment and dimensions may alter the current patterns in the area significantly enough to affect navigation, particularly in the bend and the intersections of the cutoff channel. The navigation study will also aid in the refinement of widths of the recommended channel improvements. The design ship draft is being increased significantly, and the behavior of this ship in the proposed channel alignment should be determined. 


\section{Test Conditions}

The three conditions tested were the existing condition, the proposed condition, and the existing condition deepened to $18.0 \mathrm{ft}$ mlw. The existing condition and the proposed condition (Figures $4 a$ and $4 b$, respectively) were tested as previously discussed. The pilots documented that they presently bring in ships of the size of the proposed design vessel. Therefore, it was felt that if the existing condition were deepened, transits of this size vessel could occur with no widening. All runs were made with flood tide and a 20 -knot wind from the south. These conditions were selected based on a discussion with the senior local pilot. Both the existing channel and the existing channel deepened to $18.0 \mathrm{ft}$ mlw used a 500 -hp tug while turning. When the proposed condition was run, a 1,000-hp tug was available.

Two ships were tested in the simulations. The Bermuda Islander was used to represent the size ship that most frequently transits the Salem River. It is $262 \mathrm{ft}$ long with a beam of $43.3 \mathrm{ft}$, and the draft used was $15.5 \mathrm{ft}$. This represents the adjusted draft restriction after the completion of the 1988 maintenance dredging. The proposed traffic was represented by a ship with dimensions of 327 by $49.9 \mathrm{ft}$ with a draft of $21.5 \mathrm{ft}$. The ship models were provided by BMT, International ${ }^{1}$. The Salem River pilots indicated that they bring ships larger than the proposed design ship into the existing channel. The U.S. Army Engineer District, Philadelphia, was notified of the pilots' opinions on this matter, and it was decided to continue with the original choice of design ship.

Current data for the simulation were provided by the TABS-MD hydrodynamic numerical model (RMA-2) developed at the U.S. Army Engineer Waterways Experiment Station (WES). The model was composed primarily of two-dimensional elements except for one-dimensional elements from Kelly Point to Trenton, NJ (Figure 5). Because prototype field measurements were not available until near the end of the hydrodynamic modeling schedule, several conservative precautions were made to ensure the

\footnotetext{
1 V. Ankudinov. (1991). "Hydrodynamic and mathematical models for ship maneuvering simulations of two small cargo ships in support of WES Salem River navigation study," Report No. 9292-002, prepared under Contract No. DACW 39-91-D-006 by BMT, International, Inc., Columbia, MD, for the U.S. Army Engineer Waterways Experiment Station, Vicksburg, MS.
} 


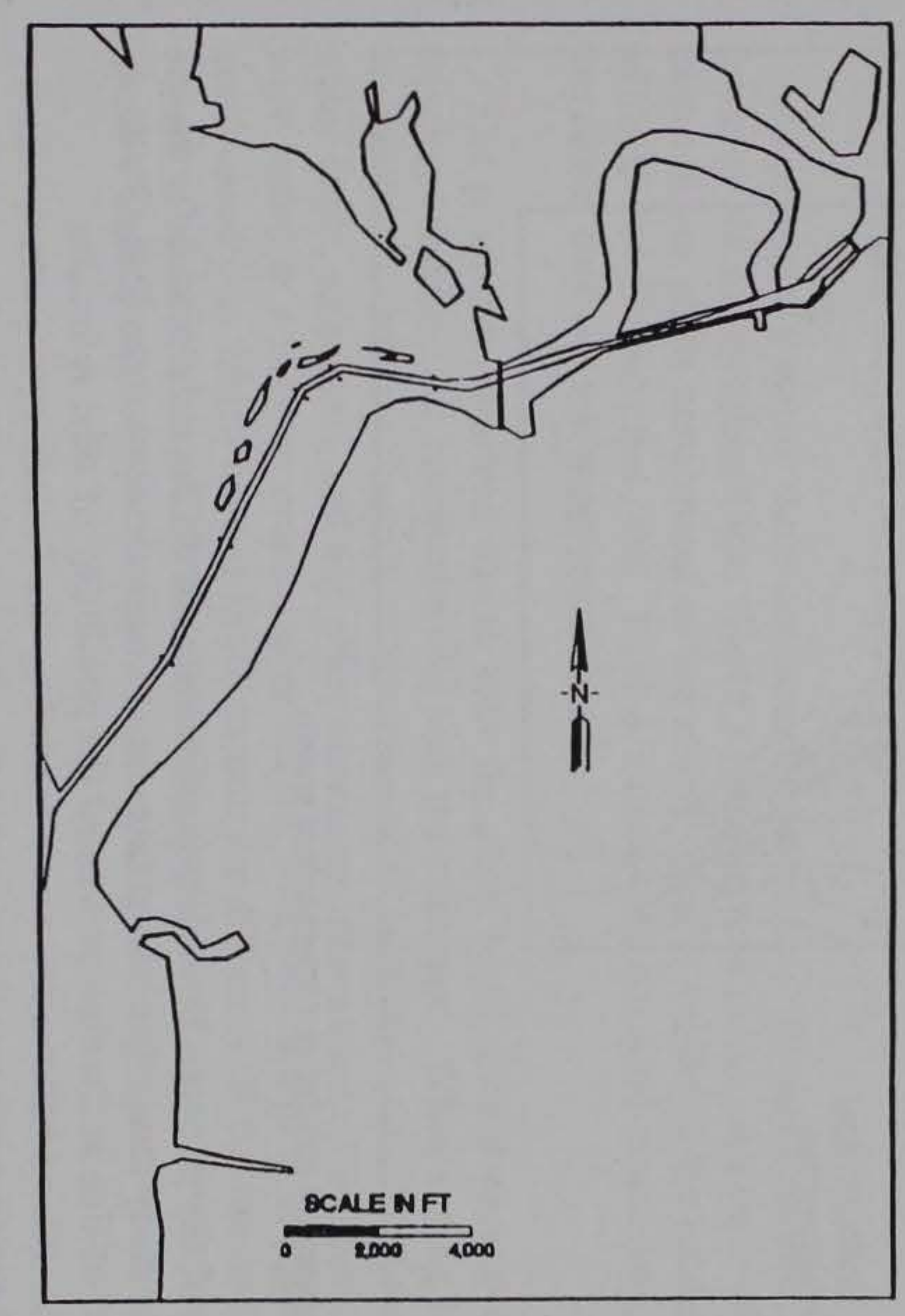

a. Existing condition

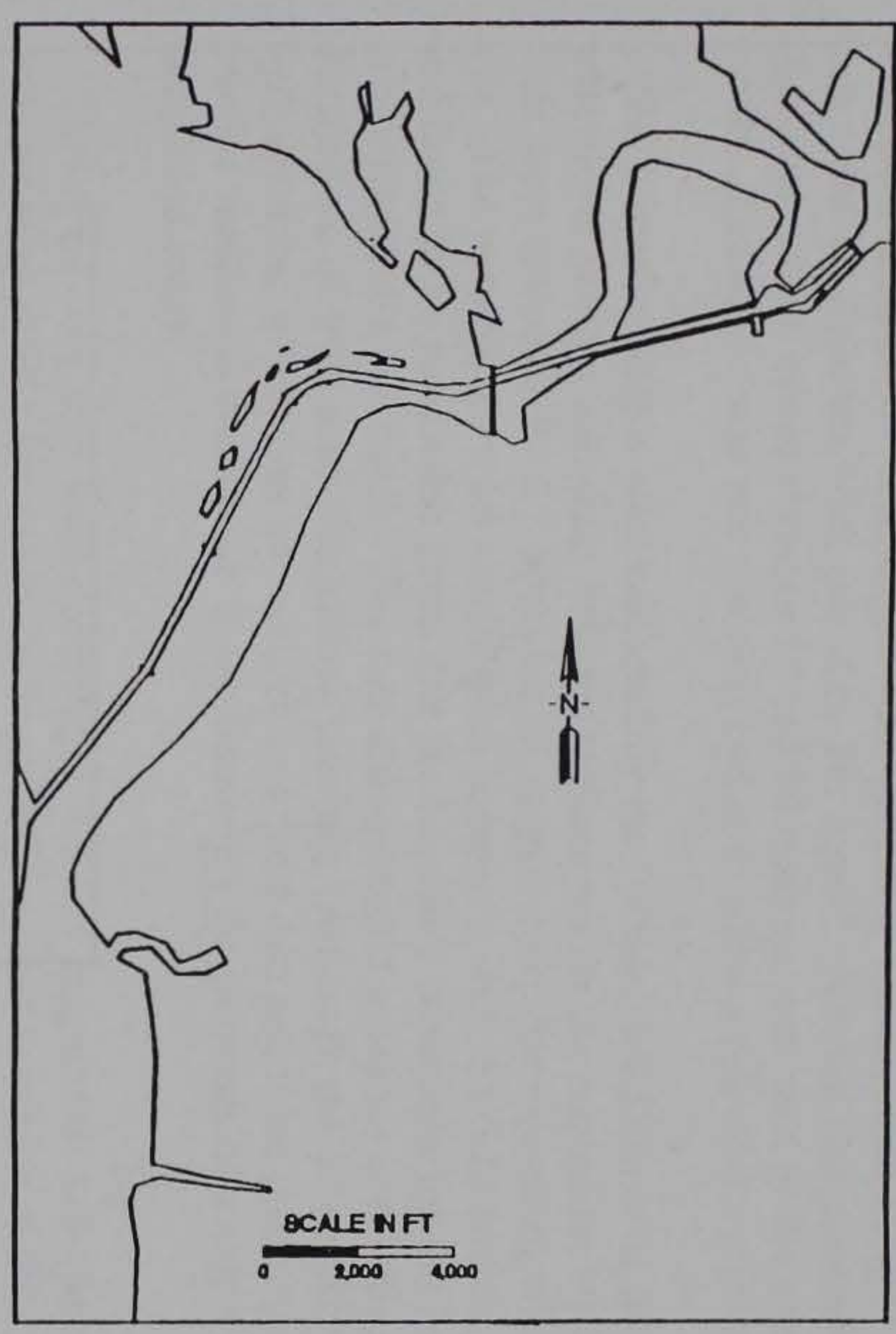

b. Proposed condition

Figure 4. Channels tested 


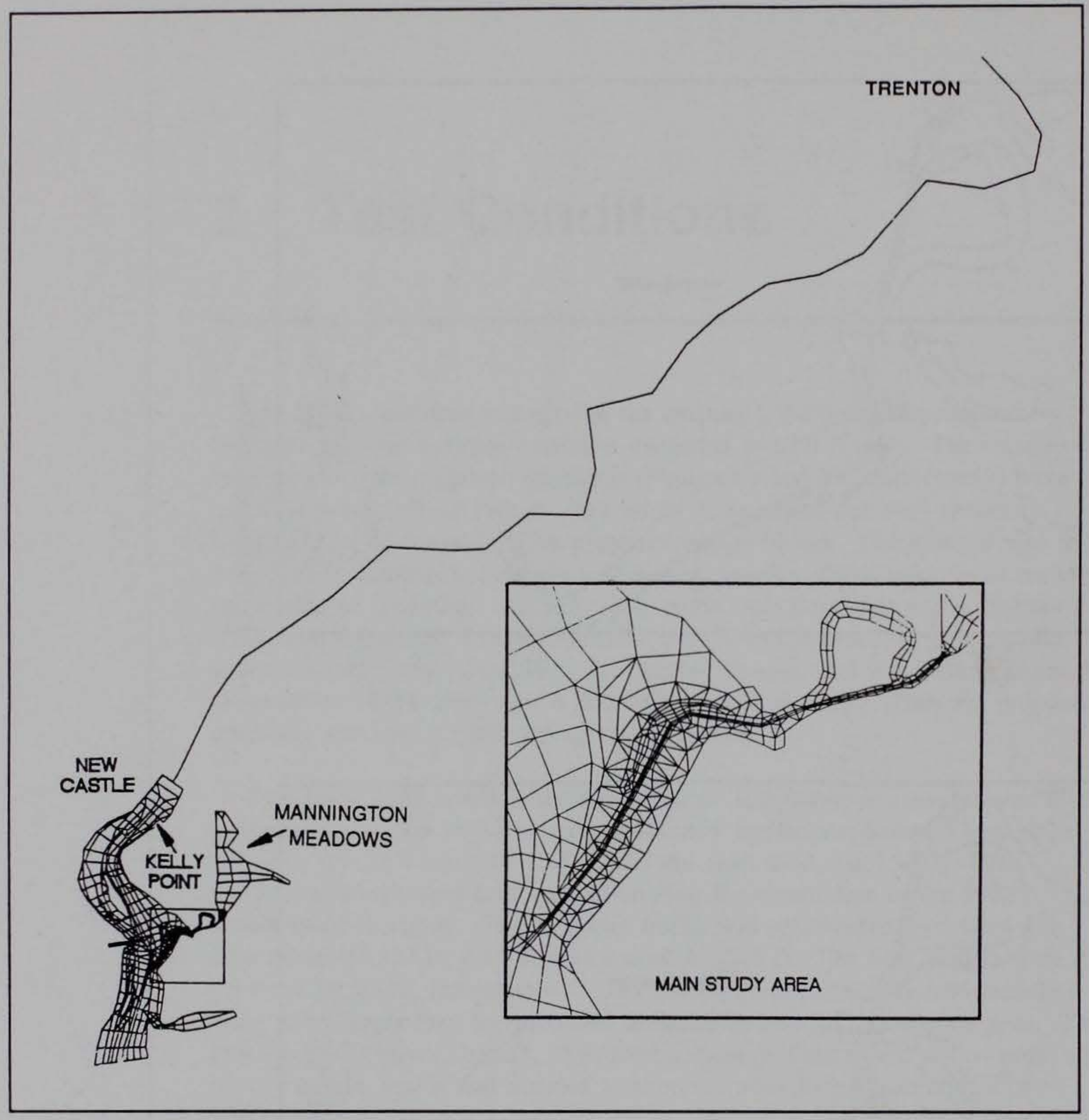

Figure 5. TABS-MD numerical model computational mesh

success of the project. Boundary conditions were deliberately placed far away from the study area. The use of one-dimensional elements from Kelly Point to the head-of-tide at Trenton prevented the possibility of tidal reflection problems. Good bathymetry was provided by the Philadelphia District, which allowed for accurate resolution within the study area. Data provided by the Philadelphia District permitted the large shallow tidal storage area called Mannington Meadows to be incorporated into the model.

A mean discharge boundary condition of $18,000 \mathrm{cfs}$ for Trenton was obtained from previous physical modeling work on the Delaware River 
conducted at WES in the mid-1970' ${ }^{1}$. The spring tide boundary condition was derived from predicted tide tables for 1 April 1991. Tidal phasing results within the model were checked between the ocean entrance and Trenton with data obtained from the work edited by Dr. Ippen ${ }^{2}$. A small computational time-step, which varied between 15 and 30 minutes, was used in the numerical model. The model was run two tidal cycles to allow a full tidal cycle spin-up.

Field measurements were collected by the Philadelphia District at five water-level stations and three velocity stations within the immediate study area. Data were collected for 2.5 hours on 15 August 1991 corresponding with low tide. The numerical model results were compared with the field current data and found to be reasonable given that the boundary conditions for the two comparisons did not match. The data also provided guidance concerning the distribution of flow near Sinnicksons Landing. Although the Salem River hydrodynamic model was not verified to a field data set, these precautions provide reasonable confidence in the results for the purposes of a ship simulation study.

However, even with these precautions, velocity magnitudes and directions were adjusted during the validation to reflect the pilot's opinion of the current effects in the existing condition. The output of the TABS-2 model and the simulator input are shown in Figures 6 and 7, respectively. Changes had to be made in the current directions and magnitudes at the turn and through the cut during validation. The currents had to be increased in magnitude in both locations from that computed by TABS- 2 .

As previously stated, three conditions were tested. Twenty-four runs were made of six run combinations. Table 1 lists the runs made. All three of the Salem River pilots participated in the study. Pilot A validated the model and pilots B and C made test runs. Pilot A's runs were not used in analysis; therefore, they are not shown in Table 1.

The procedure followed was to have the pilots make several runs of the existing condition for familiarization with the simulator. When testing began, the pilot was shown a diagram of the channel to be tested and told of the water depth, ship draft, and any other necessary information. The conditions were tested in a random order. After the run was over, the pilot completed a questionnaire in which he was asked to rate the difficulty of the run and the accuracy of the simulator. When the testing period was over, the pilot was given a final questionnaire that asked his opinion of the project.

1 J. V. Letter, W. H. McAnally. (1975). "Hydrodynamics of the Delaware River Estuary model," Technical Report H-75-8, U.S. Army Engineer Waterways Experiment Station,

Vicksburg, MS.
2 A. T. Ippen, ed. (1966). Estuary and coastline hydrodynamics. McGraw-Hill, New York, 534-544. 


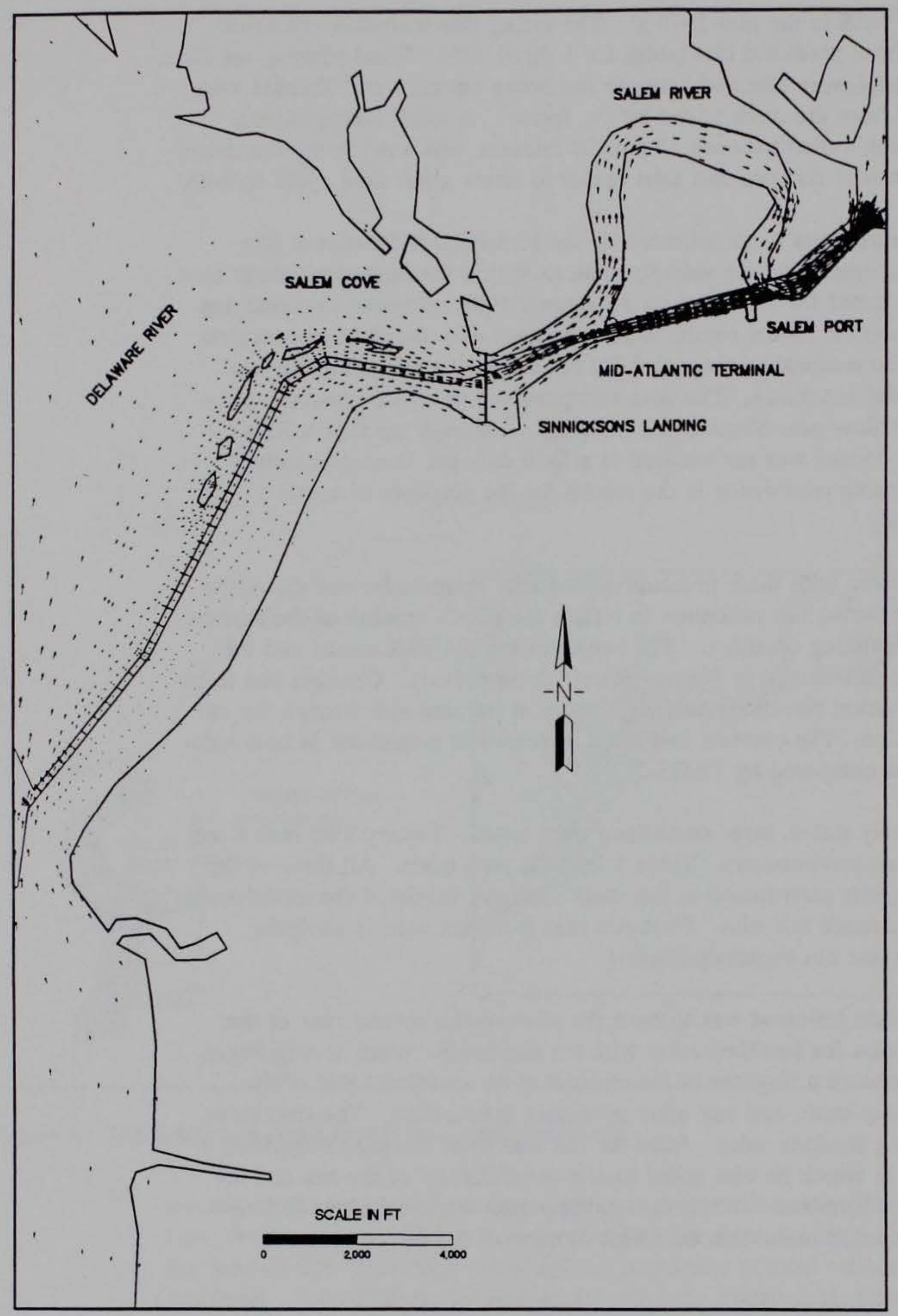

Figure 6. Existing condition, TABS-2 output 


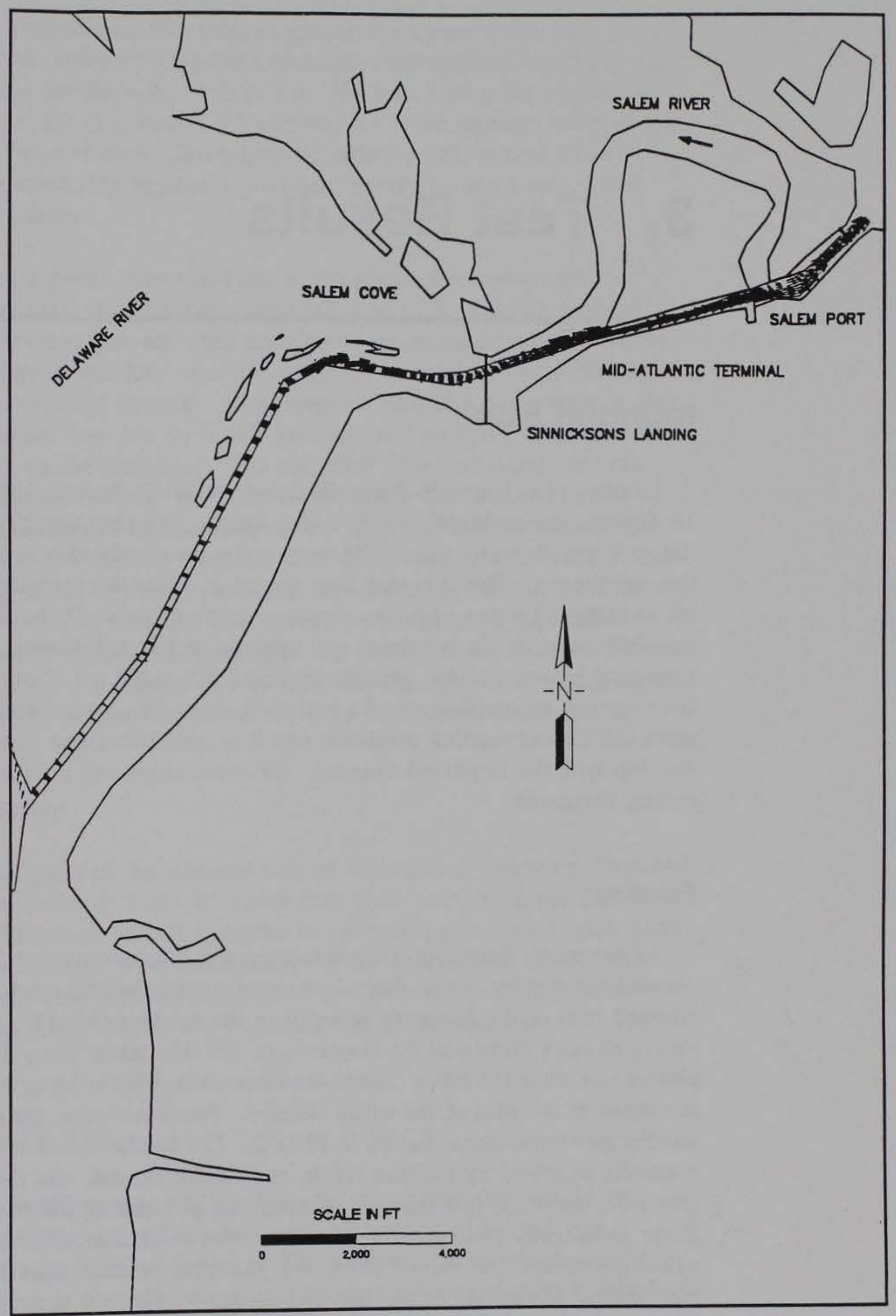

Figure 7. Existing condition, simulator input 


\section{Test Results}

\section{Inbound Runs}

Inbound runs began in the main Delaware River channel with a heading of 16 degrees and an initial speed of 10.0 knots. The ship was piloted into the Salem River channel, around the turn, under the overhead power lines, and through the cut. The ship was then turned in either the naturally deep water in the existing condition or in the proposed turning basin. It should be noted that presently most traffic is export, and inbound ships are ballasted, not loaded. Loaded ships were tested because limited funding did not allow the development of coefficients of a ballasted ship. The loaded ships represent a more difficult navigating condition and it is anticipated that some imports may develop with the improved channel. Ballasted ships will not have significantly greater clearance.

\section{Existing}

As expected, the pilots were able to transit into the existing Salem River channel without incident. Plate 1 shows a composite ship track plot of the inbound runs of the Bermuda Islander in the existing channel. A track plot shows all runs illustrated by snapshots of the ship taken every 25 seconds, plotted one after the other. Since the channel is 5 miles long, it is difficult to see detail in the plot of the entire channel. For this reason, the channel was broken into three areas, shown in Plate 2. The southernmost area is called the entrance, followed by the turn reach, and finally the cut. On the cut detail (Plate 3), the reach just inbound of Sinnicksons Landing where the Salem River forks away from the cut is shown to be an area of difficulty in the existing channel. As shown in Plate 1 , the other reaches are satisfactory for the existing navigating conditions and do not require any special attention.

\section{Proposed}

The inbound runs of the proposed channel were made with a ship of dimensions 327 by $49.9 \mathrm{ft}$ with a draft of $21.5 \mathrm{ft}$. These were the dimensions of the Tajo, which meet the criteria for the design ship. No maneuvering 
information was available on this ship, so assumptions were made in developing input to represent it on the simulator. Assumptions could be made for this study since the ships that will call on this port during the project life are not known and this ship model is required only to be representative of this general class and size of ship. The pilots did indicate that, except when backing, the simulated ship represents a typical poorly handling vessel that might enter Port Salem.

In the ship track plots, shown in Plate 4, the pilots demonstrate that generally they are able to maneuver within the channel boundaries without problems. As shown on the enlarged drawing of the entrance into the Salem River (Plate 5), two of the four runs exceeded the channel on the north edge as they entered the proposed channel. Since there is naturally deep water in this area, the pilots know they can go in this area and not ground. They followed the same strategy on the simulator. The cut detail (Plate 6) shows one run exceeding the channel limits to the south at the power line. Much less difficulty was encountered approaching the cut in the proposed channel than was experienced in the existing channel. The ships were turned easily in the proposed turning basin; however, one track shows the ship hitting the MidAtlantic Dock. It should be noted that several trial runs were required to develop a successful strategy for turning in this turning basin since the current pattern in the proposed condition is very different from the existing condition current pattern. The unfamiliarity with the ship also caused problems.

\section{Existing deepened}

The ship track plots of the inbound runs of the existing condition deepened to $18 \mathrm{ft} \mathrm{mlw}$ are shown in Plate 7. These runs were made with the Tajo as the design vessel. The track plots are similar to the existing condition track plots in that successful transits were made except in the approach to the cut as shown in Plate 8 . This plate also illustrates the difficulty encountered by the pilots when attempting to turn in the existing maneuvering area.

\section{Outbound Runs}

Outbound runs began at the Salem Port and proceeded through the cut, under the power cable, around the turn, and out to the Delaware River. Outbound runs began with a heading of 225 degrees and an initial speed of 4.1 knots. Turning is normally accomplished on the inbound transit; therefore, it was not tested as part of the outbound run.

\section{Existing}

The ship track plots of the Bermuda Islander transiting outbound in the existing condition are shown in Plate 9. This track plot indicates a difficult run throughout the cut area, shown in Plate 10, in spite of no significant 
excursion beyond the channel boundary. Plate 11 shows groundings occurred in the turn out to the Delaware River. The pilots were not satisfied with the simulation in this area. They said that they normally made one sweeping turn around the two buoys. On the simulator, they made one turn, held course, and then proceeded with a second turn. One pilot suggested, "the turn at marker numbers 8 and 10 should be shortened to be more realistic." However, no justification could be made for this since the buoys were located at the exact state planar coordinates shown on the navigation charts. The validation pilot remarked that the currents in this area were not acting properly. Many changes were attempted, but it seems that these changes did not correct the problem. The lack of data to verify the current model could have allowed significant error in this region. Plate 12 shows that less difficulty was encountered in the entrance reach.

\section{Proposed}

The track plots of the proposed condition outbound runs with the Tajo are not as smooth as with the existing condition. Groundings are seen in Plate 13 in the turning basin, at Sinnicksons Landing, just before the power line, and in the turn.

\section{Existing deepened}

With the existing condition deepened to $18 \mathrm{ft} \mathrm{mlw}$, the groundings are not as severe as in the proposed condition, as shown in Plate 14. This indicates that the pilots' unfamiliarity with the channel limits, bank conditions, and new current patterns may have caused these groundings. Plate 15 shows one trackline exceeding the channel limits on the north side at Sinnicksons Landing. This area has already been identified as needing improvement.

\section{Pilot Questionnaires}

To determine the pilots' thoughts about the simulator and proposed deepening, two questionnaires were prepared to document their comments and rate the runs. One was given to the pilots after each run, and a final debriefing questionnaire was given to the pilots upon completion of the test period. For each run, the pilots were asked to give a rating on the difficulty of the run, the effect of the current on the ship, the amount of the pilot's attention required by the run, and the danger of grounding or hitting an object. The general trend of the pilots' ratings was that the existing channel received the lowest rating, indicating that it was the easiest channel to navigate. The proposed channel was given a rating slightly higher than that of the existing channel, and the existing deepened to $18 \mathrm{ft}$ mlw received a rating much higher than either the existing or proposed channels. 
Plate 16 shows the ratings for the inbound runs. Three of the four criteria followed the expected pattern. The existing channel required more of the pilots' attention than the proposed channel. It seems the pilots felt they had more area in the proposed channel and did not have to concentrate on staying in the channel. In this case, the existing channel rated more closely to the existing deepened channel than the proposed channel.

The same pattern is shown in the outbound runs (Plate 17). The normal trend is followed for difficulty of run, the effects of the current on the ship, and danger of grounding or hitting an object. The only criterion that does not follow this pattern is amount of attention required. In the outbound case, the proposed channel, not the existing, rated higher than expected. The pilots seemed to have had to concentrate more on the proposed channel because of their unfamiliarity with the turn. It could also be possible that the pilots interpreted this question differently than intended. In this case, the proposed channel rating is the same as the existing channel deepened.

\section{Discussion}

The pilots felt that the radar-based simulation done in this study was similar to entering the port with zero visibility (i.e., during a heavy rain or fog). They emphasized that this would not be attempted. Therefore, the simulation was more difficult than actual navigating conditions. For this reason, the channel design may be conservative, i.e., wider than optimum.

The modeled existing condition was shown to be adequately represented for the present traffic into Port Salem. The need for improvement is recognized in the area of Sinnicksons Landing entering the cut when transiting inbound. Loaded inbound transits are not frequent in the existing channel.

The proposed channel width of $180 \mathrm{ft}$ is acceptable in most areas. This was confirmed by the pilots, who stated on their final questionnaires that widening the channel to $180 \mathrm{ft}$ and enlarging the turning basin would provide the margin of safety necessary to negotiate vessels of 21.5 - $\mathrm{ft}$ draft. The $180-\mathrm{ft}$ channel is not adequate near Sinnicksons Landing between the power cable and the cut. Also, the turn outbound heading toward the Delaware River needs improvement. The existing channel deepened to $18 \mathrm{ft}$ mlw illustrates the ability of the pilots to navigate in a channel narrower than the proposed design.

Two areas were apparently not simulated as accurately as desired based on pilot evaluation. The first area was in the turn. The pilots' opinion was that the model ship did not handle in this area as they expected it should. While the currents were adjusted, it is not clear what was causing the unexpected behavior. There could be different bottom conditions from those indicated on the maps and outside the detailed survey data available. This could change the currents or the bank effects in this local area. The proposed turn wideners of approximately $265 \mathrm{ft}$ fit into the design guidance range of a ship with good 
controllability. Since no data were available on the maneuverability of the design ship, a more conservative design may be required.

The second area where the simulation was not as accurate as planned was in the turning basin. No information on maneuvering was available on the Tajo, so assumptions were made in developing a ship model for the simulator. The pilots felt this ship responded too efficiently to the rudder commands when backing. For this reason, it was much easier for the pilots to turn the ship. The proposed design, based on the Corps design criteria, which is thought to be conservative, will not be modified. Despite these two areas, the pilots rated the overall simulation 8.5 out of 10,10 being the most accurate rating.

Experience in working with pilots shows that they attempt to stay at the center of the two banks. This has been illustrated again in these data even though the north bank was cut back on a $1 \mathrm{~V}$ on $4 \mathrm{H}$ slope to show the added width. Therefore, the $80-\mathrm{ft}$ widening to the north side of the cut is not efficient. A smaller widening symmetrical about the center line between the banks would be more beneficial.

\section{Proposed Modifications}

Based on this study, it is recommended that the navigation channel be modified as shown in Plate 18. Plate 19 compares the recommended channel versus the District's proposed design in the cut. In the turning basin, it would be beneficial for the channel to extend south an extra $40 \mathrm{ft}$. This would cause the channel to be near the Mid-Atlantic Shipping Terminal. Also, a widener should be introduced at the entrance to the turning basin. The $100-\mathrm{ft}$ measurement was made along the alignment of the proposed flare into the turning basin. This flare occurs over a distance of $750 \mathrm{ft}$. If the channel were rotated slightly so that it would run $30 \mathrm{ft}$ to the south of the proposed channel alignment at the entrance to the cut, this would be a great benefit to the pilots both when subjected to the flow of the old Salem River on inbound runs and in setting up for the anticipated currents on the outbound runs. However, there is no need to make this channel $180 \mathrm{ft}$ wide; $150 \mathrm{ft}$ would be sufficient if aligned correctly. The channel at Sinnicksons Landing, on the other hand, is not adequate at $180 \mathrm{ft}$. A $250-\mathrm{ft}$ channel is recommended at this location. As shown in Plate 20, the extra widening being recommended is in areas already having depths of $12 \mathrm{ft}$ or greater. This is the dredged channel plus naturally deep water in the turning basin and at Sinnicksons Landing. It is not anticipated that these channel widenings would increase dredging volumes significantly. Plate 21 shows the proposed track-lines in the recommended channel. In most cases, the recommended channel contains the track-lines with adequate clearance on either side.

The recommended channel has a southern boundary $550 \mathrm{ft}$ from the tower supporting the overhead power line. As shown in Plate 22, the restricting air 
clearance would be $95 \mathrm{ft}$. The maximum air draft is set by the pilots at $85 \mathrm{ft}$. The existing channel provided a $100-\mathrm{ft}$ clearance giving an extra $15-\mathrm{ft}$ air clearance above that maximum air draft limit. The recommended channel provides only $10 \mathrm{ft}$ of clearance. The design ship Tajo with a ballast draft of $11 \mathrm{ft}$ would require that the height of the power cable be $104 \mathrm{ft}$. Thus, the present channel air clearance at $100 \mathrm{ft}$ is not satisfactory for this ship in a ballast condition. The design ship will have to come into Salem with a heavier ballast load than normal. However, loaded design ships will be able to clear in the recommended channel.

On the turn plot (Plate 23), the turn widener at Sinnicksons Landing has been enlarged to $350 \mathrm{ft}$. This is shown in Plate 24 to be in water of a depth of $12 \mathrm{ft}$ or greater. The channel then returns to a width of $180 \mathrm{ft}$. The turn heading toward the Delaware River has been widened to a constant width of $250 \mathrm{ft}$; however, the bend wideners have been removed (Plate 23). The channel then narrows from $250 \mathrm{ft}$ to $150 \mathrm{ft}$ over a distance of $1,900 \mathrm{ft}$ and remains at $150 \mathrm{ft}$. Plate 25 shows the ship track plots of the existing channel deepened to $18 \mathrm{ft} \mathrm{mlw}$. All track-lines are enclosed in the envelope of the recommended channel with sufficient clearance for most runs. The runs of the existing channel deepened were used since the pilots used about $450 \mathrm{ft}$ in the turn in the proposed channel. As previously discussed, their unfamiliarity with the channel conditions caused them some confusion.

Plate 26 shows the channel returning to a width of $180 \mathrm{ft}$ over a distance of $2,600 \mathrm{ft}$. It remains at $180 \mathrm{ft}$ over a distance of $2,000 \mathrm{ft}$ until a flare to a width of $280 \mathrm{ft}$ at the intersection of the channel with the deep water at the Delaware River. Again, Plate 27 shows that in most of this area the depth is already greater than $12 \mathrm{ft}$; in some places the natural depths are as much as $40 \mathrm{ft}$. Plate 28 shows the track plots of the proposed condition in the recommended channel. In the reach that flares from $150 \mathrm{ft}$ to $180 \mathrm{ft}$, there is insufficient clearance on the west side of the channel. In the proposed channel condition, the pilots had this area to work with. However, Plate 29 shows that with the tracks of the deepened existing channel there is adequate clearance.

Due to limited funding on this study, the conclusions were not as definitive as desired. It may be possible to further refine the channel design with more testing. Field data should be taken during a spring tide event. The TABS-2 model should be verified to these data. Finally, simulations should be made with the visual scene showing the normal view the pilot would see out of the bridge window while piloting the ship. This information could lead to further reduction in the channel dimensions.

Two locations have been identified as possible areas of further refinement to the channel. Plate 30 shows the ship track plots of the proposed channel runs in the recommended turning basin. This plate shows that it may be possible to decrease dredging costs substantially by decreasing the size of the turning basin. This has not been included in the recommendations since the simulated Tajo responded well to rudder commands when backing. Further 
testing will be needed to ensure that a larger turning basin is not required for a ship with a more typical backing response.

Further optimization could also address the overhead power line at Sinnicksons Landing. If the channel is realigned as shown in Plate 31 , not only will the air draft be greater but the turn angle at this location will be decreased by 5 degrees, making this, in general, an easier maneuver. Plate 32 shows that the air draft with this channel will be over $100 \mathrm{ft}$.

Also shown in Plate 31 is an alternate channel. The channel is designed to accommodate a single turn instead of two distinct turns. This was done by setting the curvature on the inside of the channel approximately equal to the steady turning diameter of the ship in shallow water. This was verified as a valid approach by comparing it with the latest information on turn widening. A cutoff bend of 70 degrees would require a $450-\mathrm{ft}$ width. This is the approximate width that would be achieved by creating a cutoff bend (i.e., extending the outer edges of the straight reaches until they intersect). This turn is thought to be easier to navigate than the recommended turn. In the changes shown in Plate 31, the area is shallow, and the additional dredging cost should not be incurred without evidence that this alignment will not cause navigating hazards. Since no available data illustrate this, further study is required. 


\section{Recommendations}

The following recommendations are made beginning with the turning basin.

a. The turning basin should be widened on the southeast corner by $40 \mathrm{ft}$ (Plate 19).

b. A 750-ft-long flair on the northwest corner of the turning basin will provide a 100 -ft wider approach (Plate 19).

c. A 150 - $\mathrm{ft}$ channel should be relocated $30 \mathrm{ft}$ south as the Old Salem River cutoff entrance is approached (Plate 19).

d. The channel should be widened into a 250 -ft channel at Sinnicksons Landing (Plate 19).

e. The turn widener at Sinnicksons Landing should be increased to $350 \mathrm{ft}$ (Plate 23).

f. The two three-point turns at the turn from the entrance channel should be replaced with two turns with no wideners and a $250-\mathrm{ft}$ channel between the two turns (Plate 23).

g. A 1,900 -ft-long flare should be provided on the east side of the southwestern turn that reduces the channel from $250 \mathrm{ft}$ to $150 \mathrm{ft}$ (Plate 23).

$h$. A 150 -ft wide channel is recommended over most of the entrance channel (Plate 26).

i. A 2,600-ft-long flare is provided at the turn immediately above the Delaware River to return the channel to a $180-\mathrm{ft}$ width (Plate 26).

j. A 2,000-ft-long flare brings the channel from a $280-\mathrm{ft}$ width at the Delaware River to the 180 -ft entrance channel section (Plate 26).

The channel could be further optimized with additional testing, particularly in the turning basin (Plate 30), through the power lines and the turn from the entrance channel (Plate 31). 


\begin{tabular}{||l|l|l|l|l|l|l||}
\hline \multicolumn{2}{||}{$\begin{array}{l}\text { Table } 1 \\
\text { Test Conditions }\end{array}$} & & \multicolumn{3}{|c||}{ Pilot } \\
\cline { 5 - 8 } Test & Channel & Direction & Ship & B & C & Total \\
\hline \hline 1 & Existing & Inbound & Bermuda Islander & 2 & 2 & 4 \\
\hline 2 & Existing & Outbound & Bermuda Islander & 2 & 2 & 4 \\
\hline 3 & Proposed & Inbound & Tajo & 2 & 2 & 4 \\
\hline 4 & Proposed & Outbound & Tajo & 2 & 2 & 4 \\
\hline 5 & $\begin{array}{l}\text { Existing } \\
\text { Deepened }\end{array}$ & Inbound & Tajo & 2 & 2 & 4 \\
\hline 6 & $\begin{array}{l}\text { Existing } \\
\text { Deepened }\end{array}$ & Outbound & Tajo & 2 & 2 & 4 \\
\hline \hline
\end{tabular}




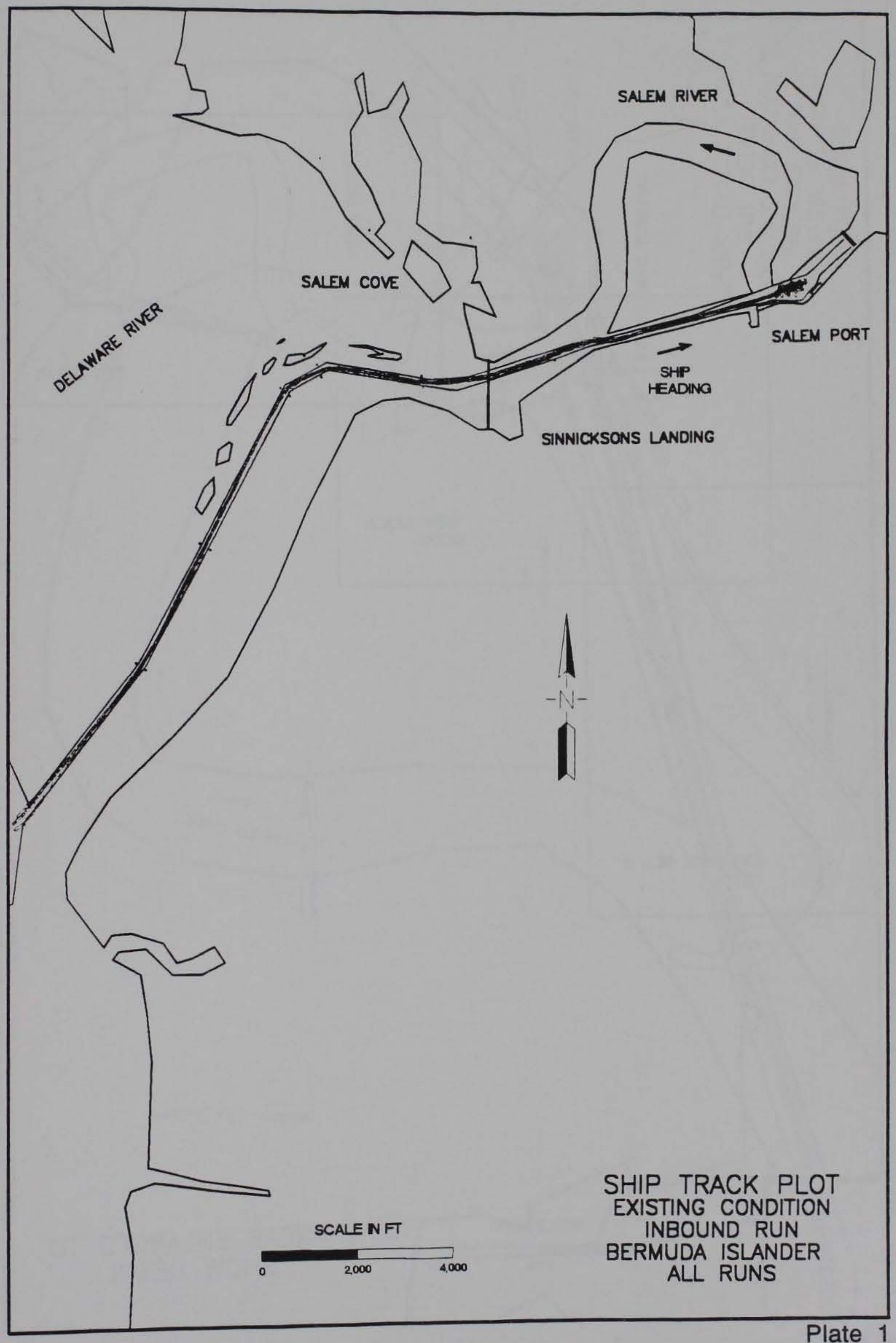




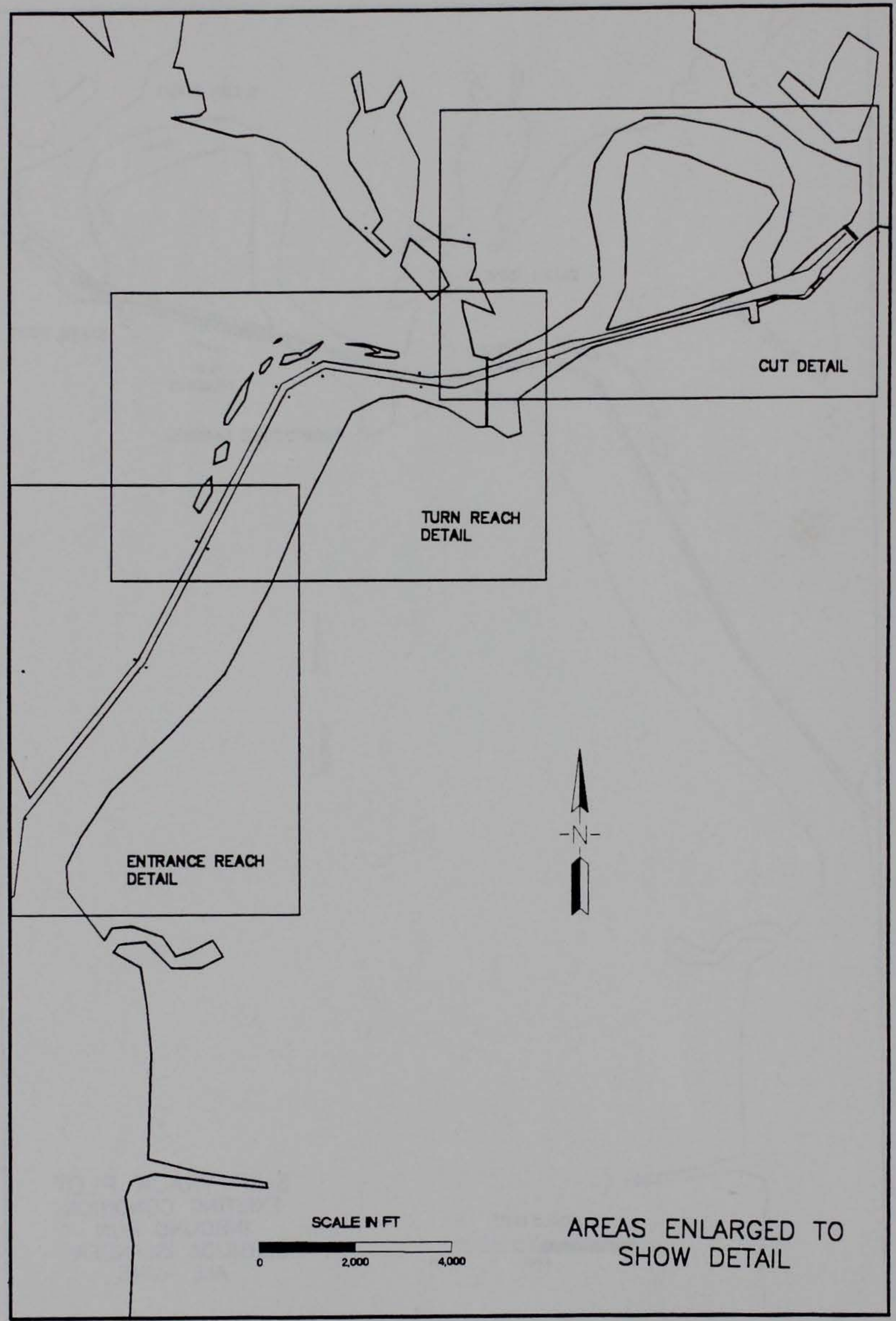

Plate 2 


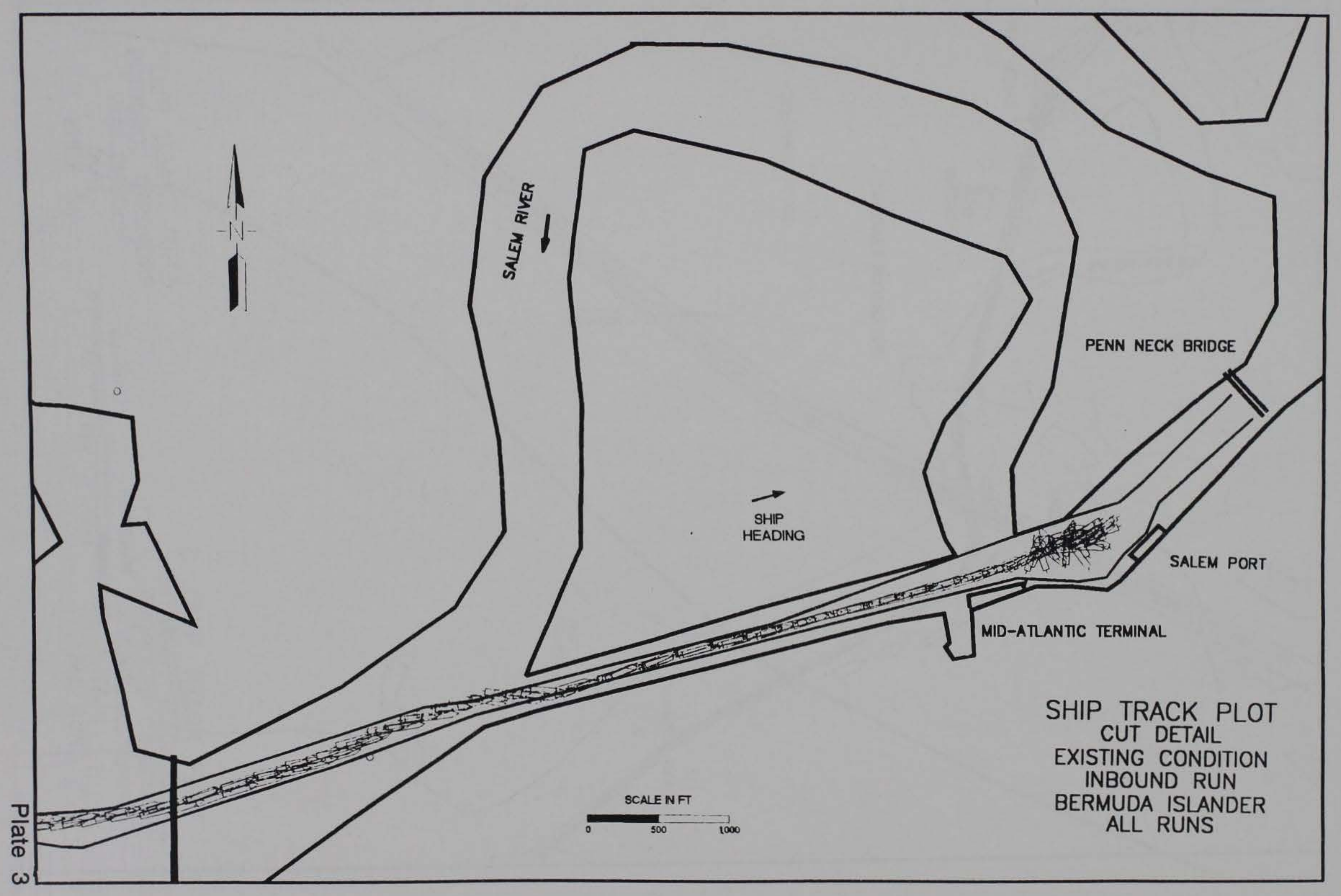




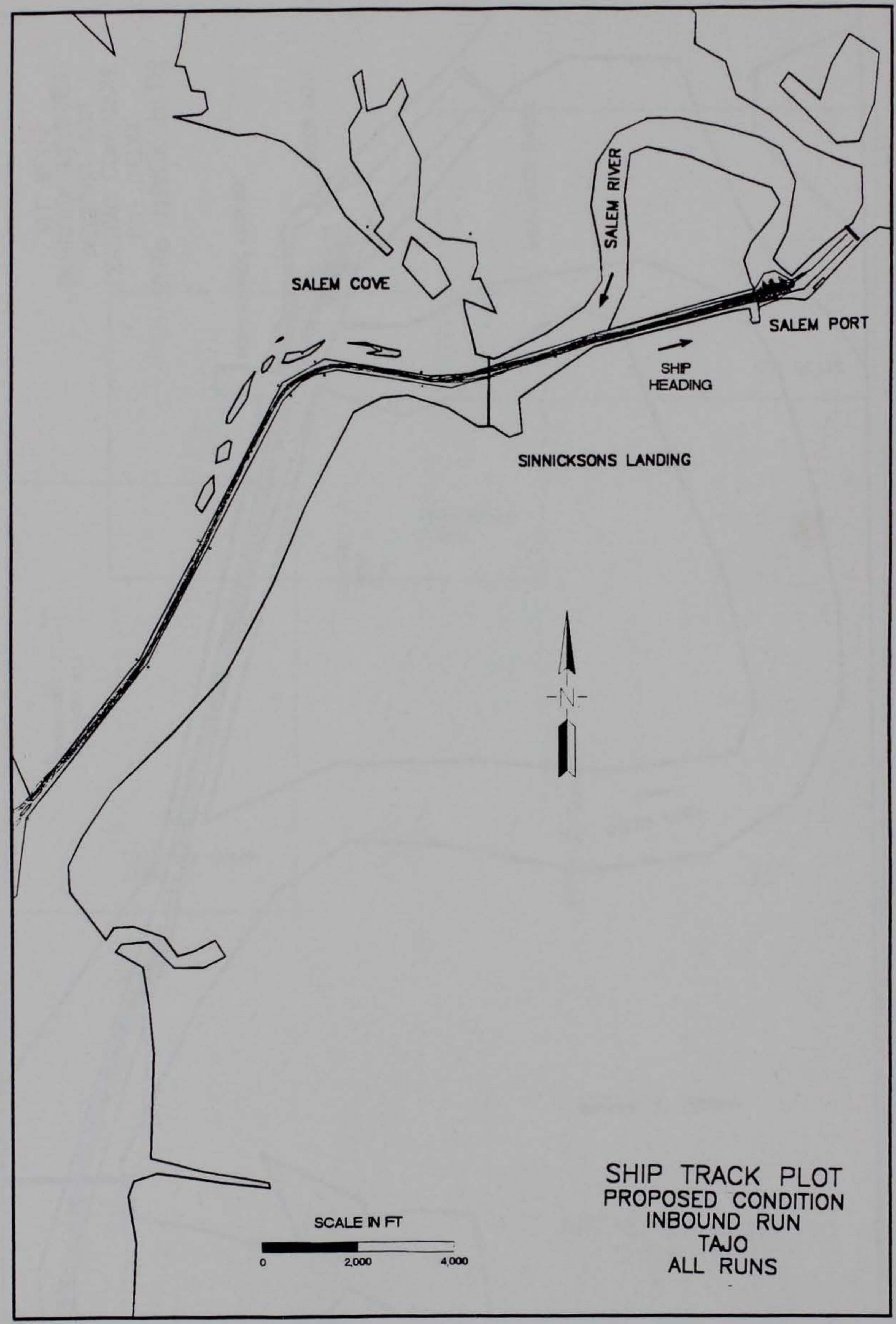

Plate 4 


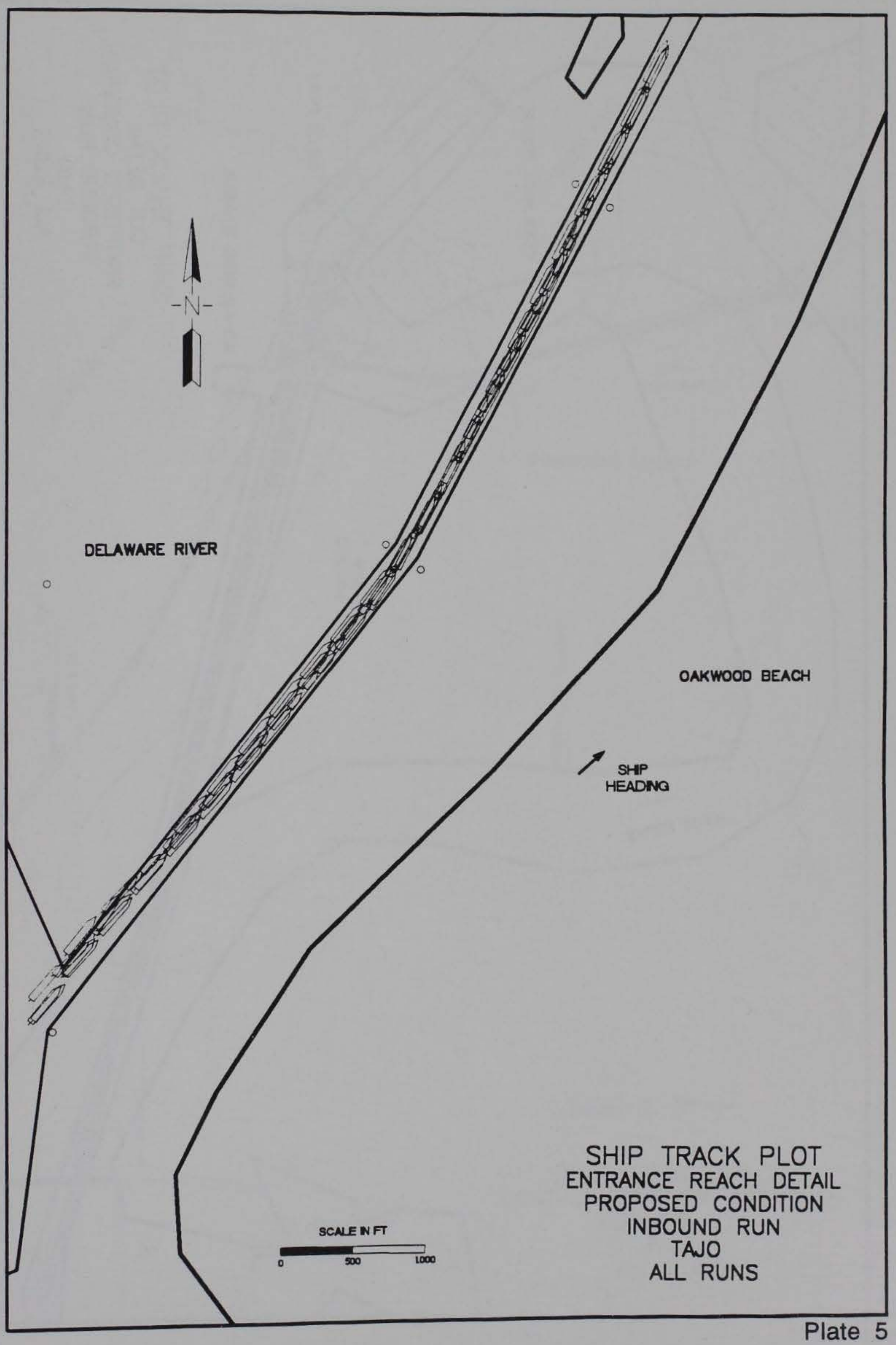




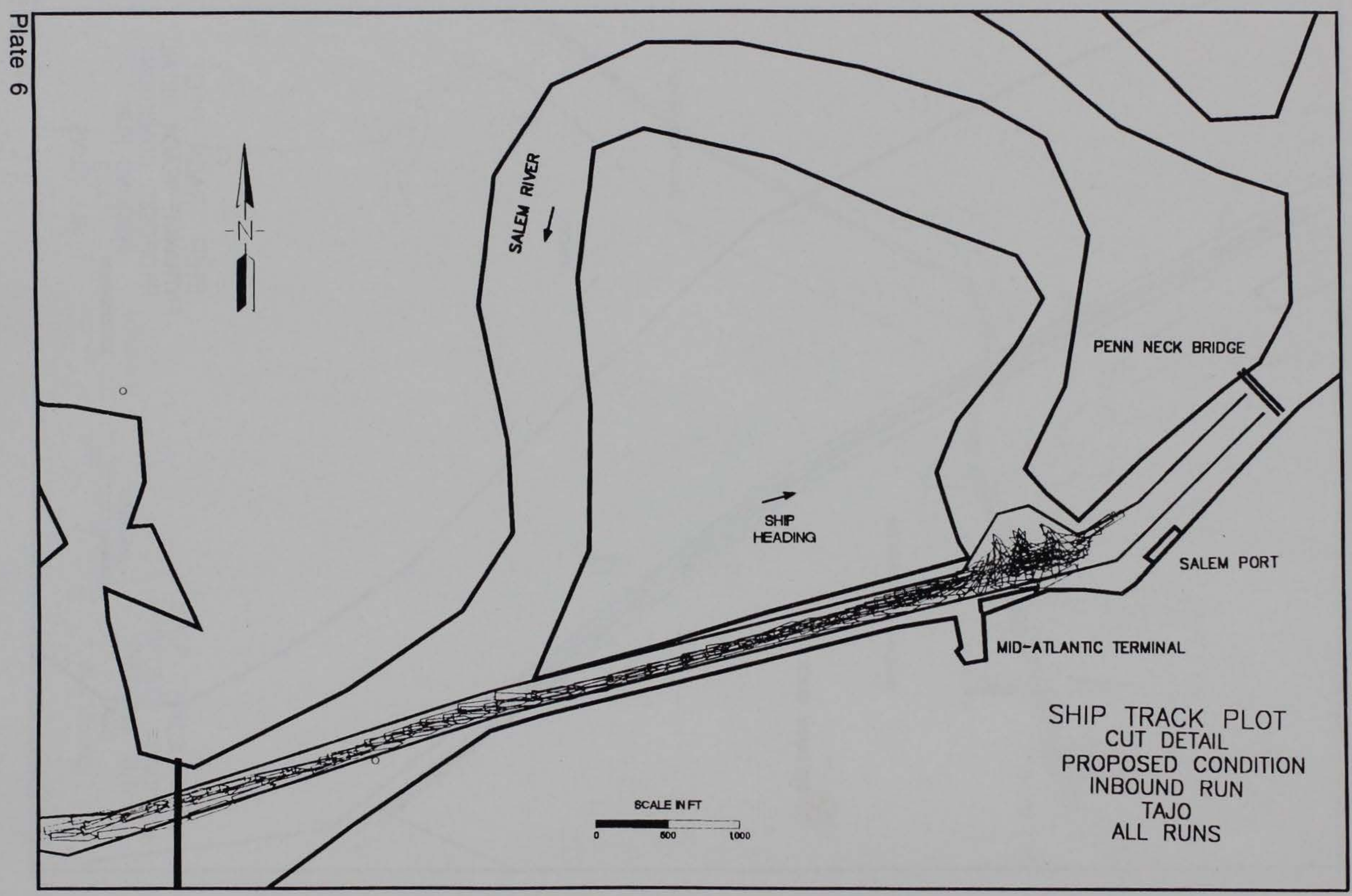




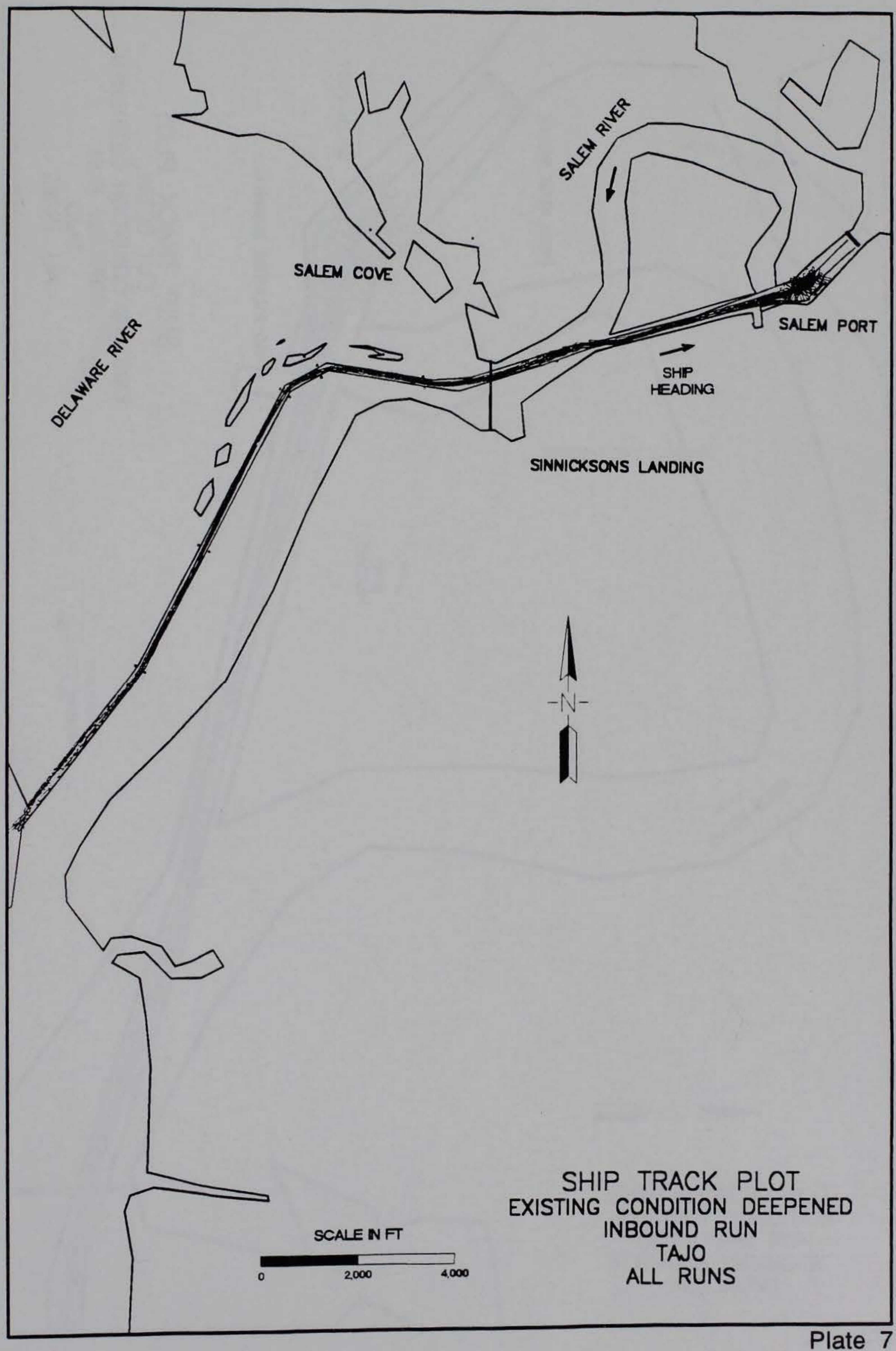




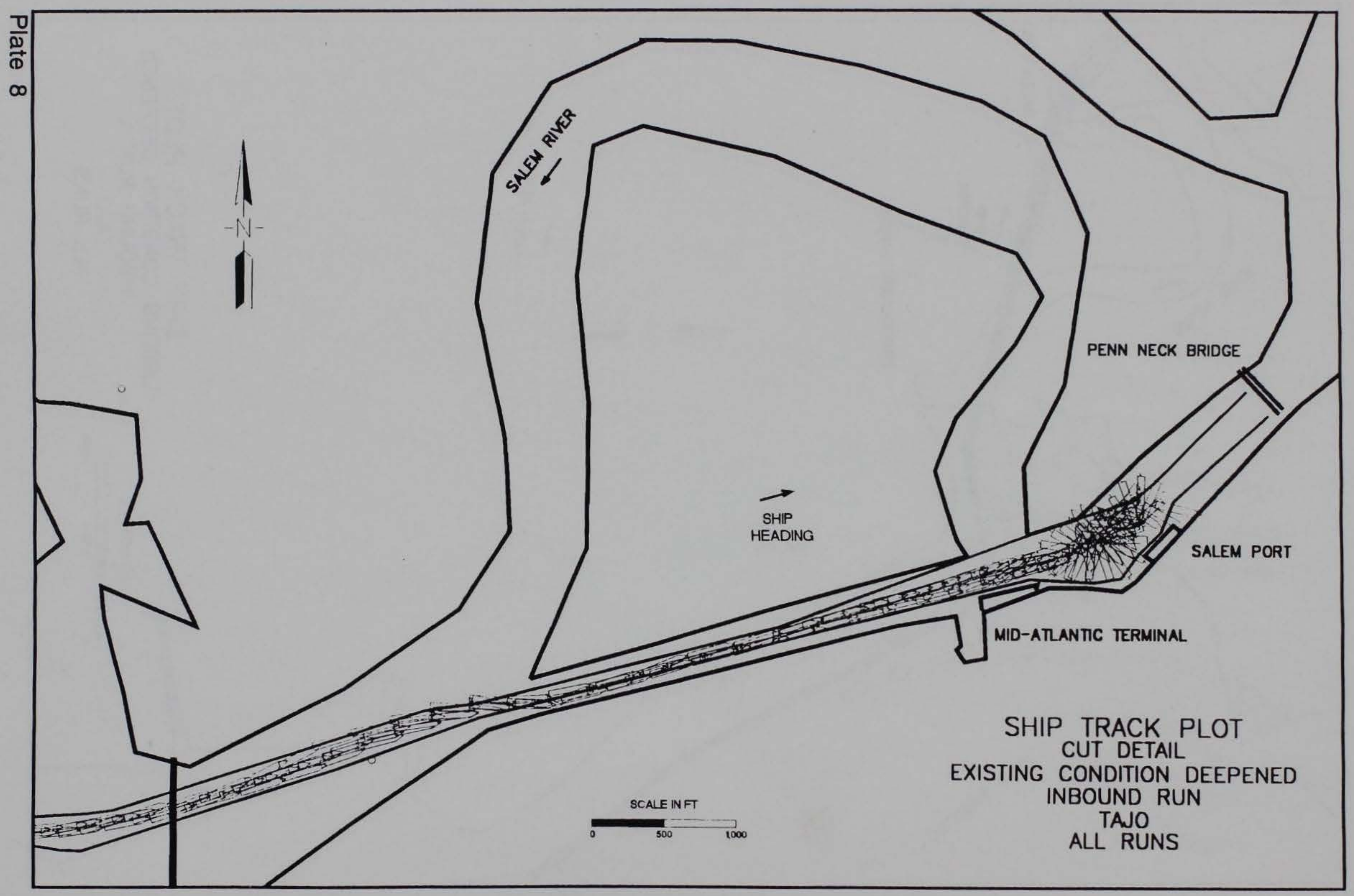




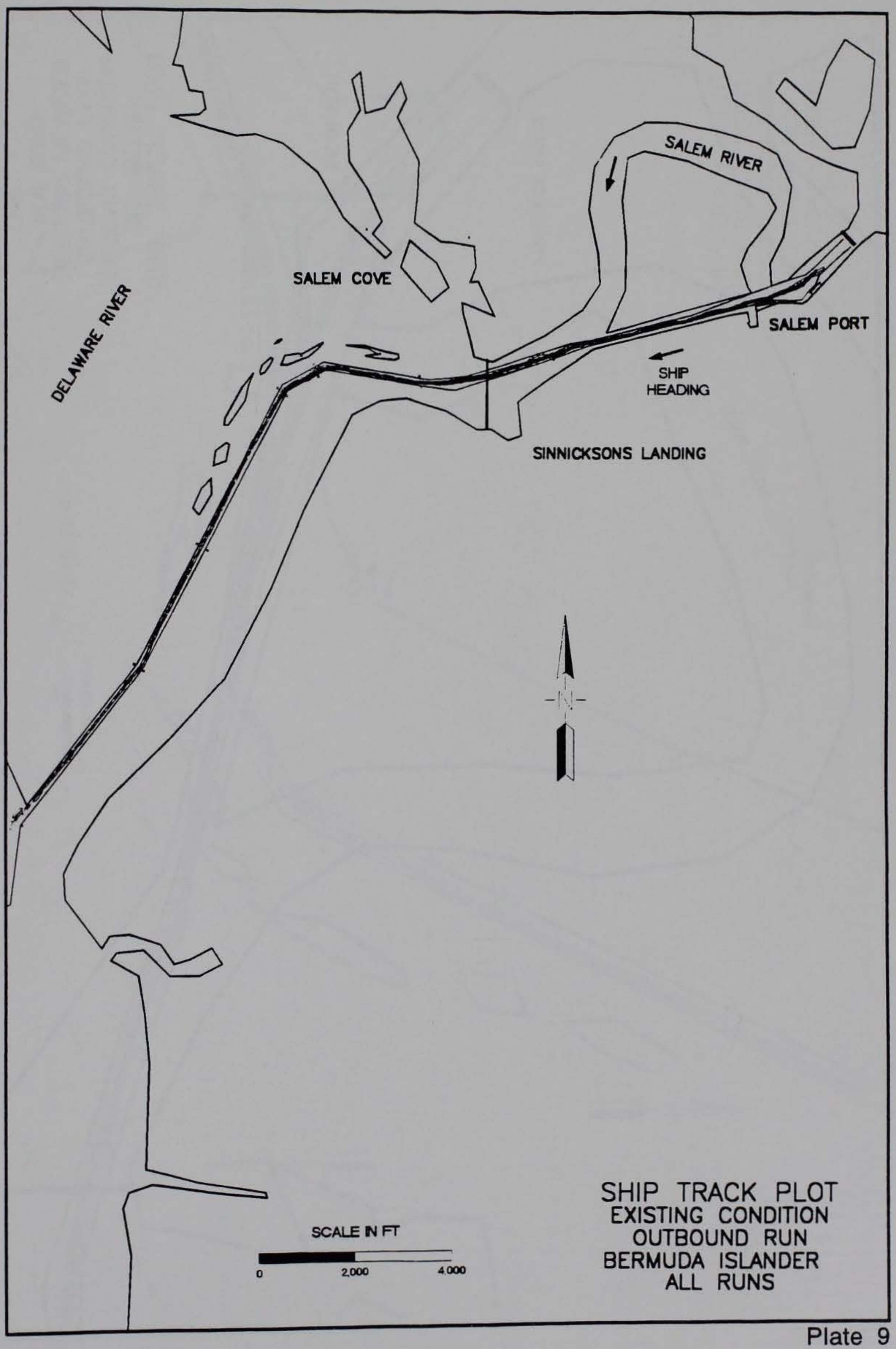




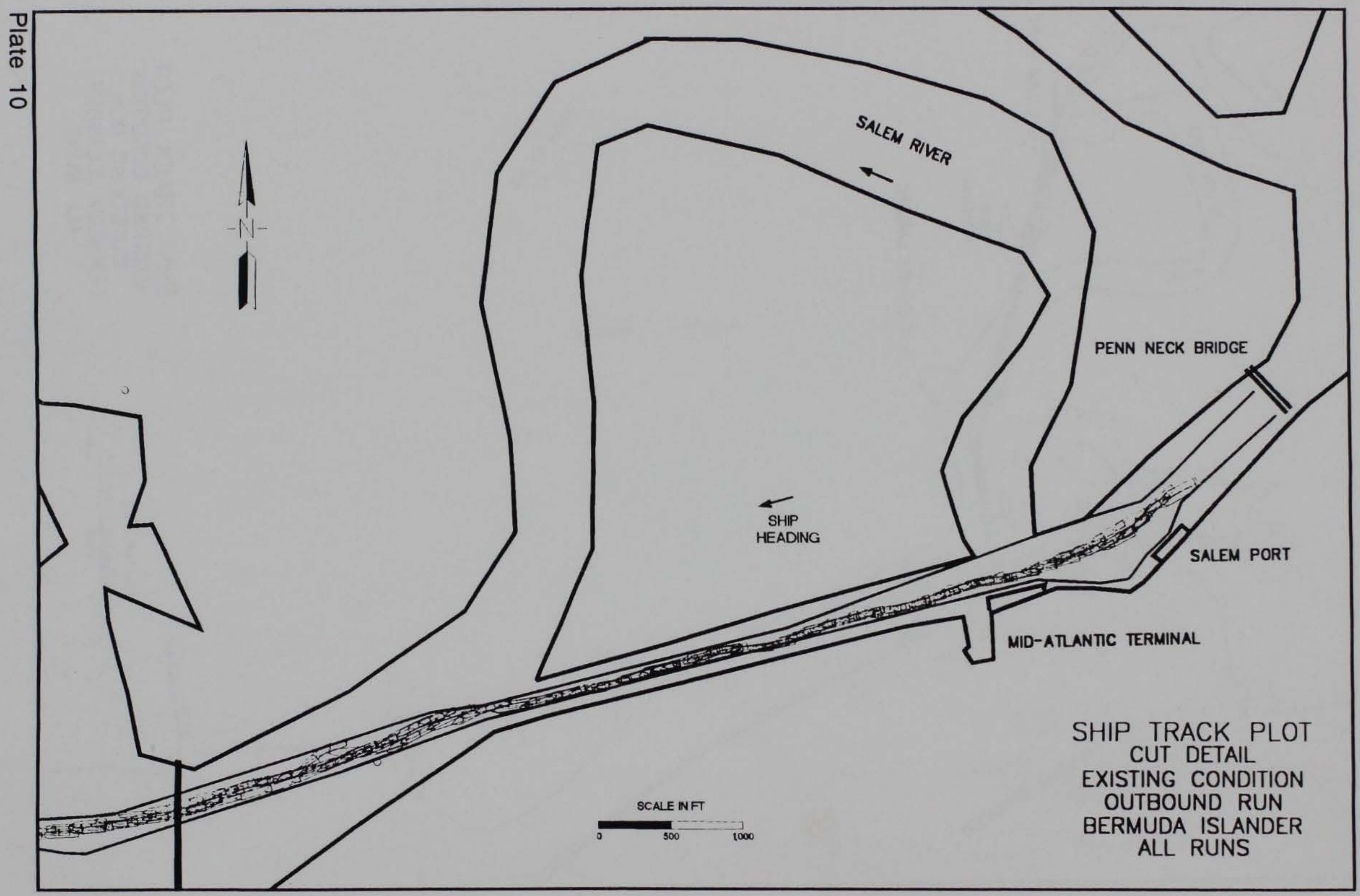




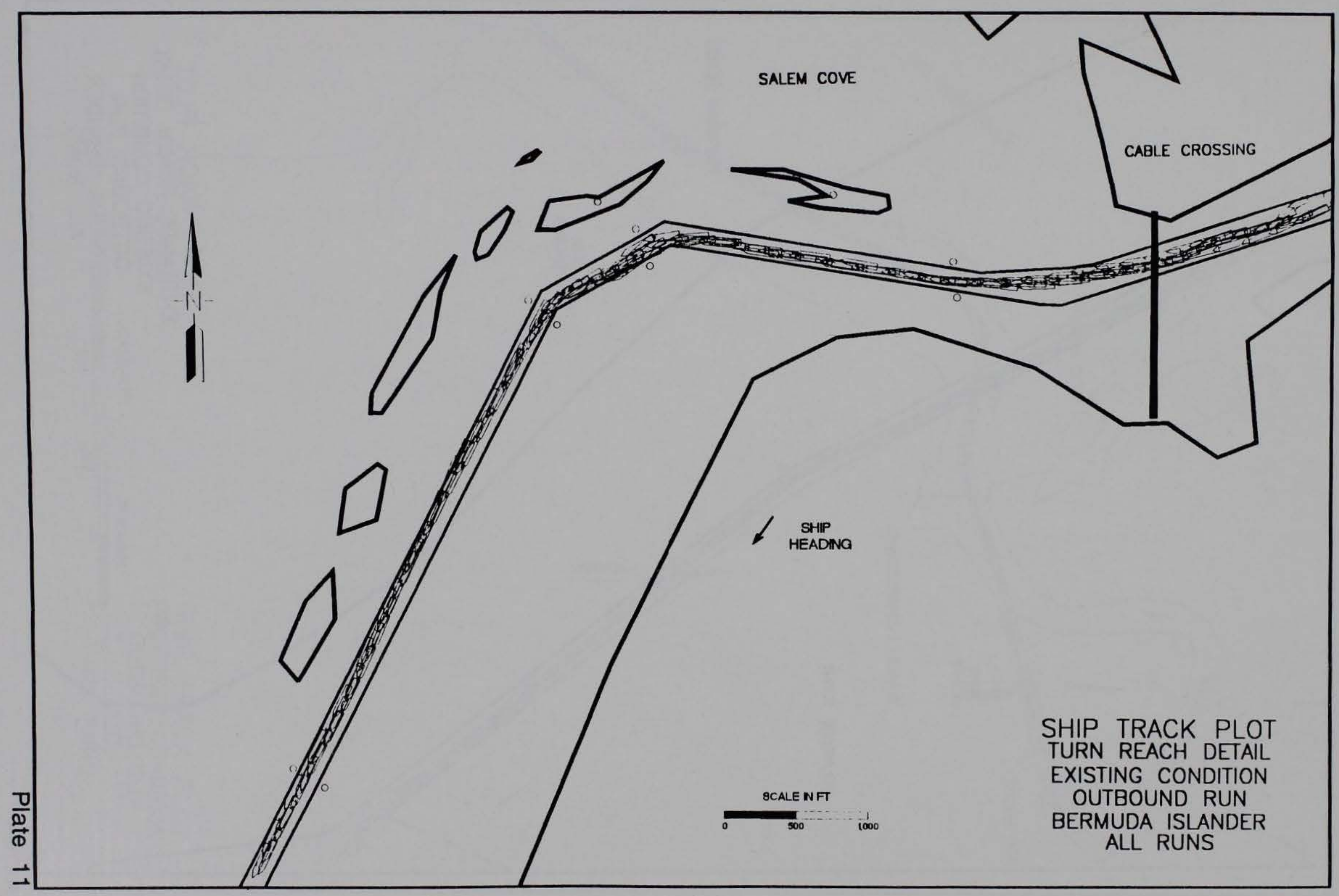




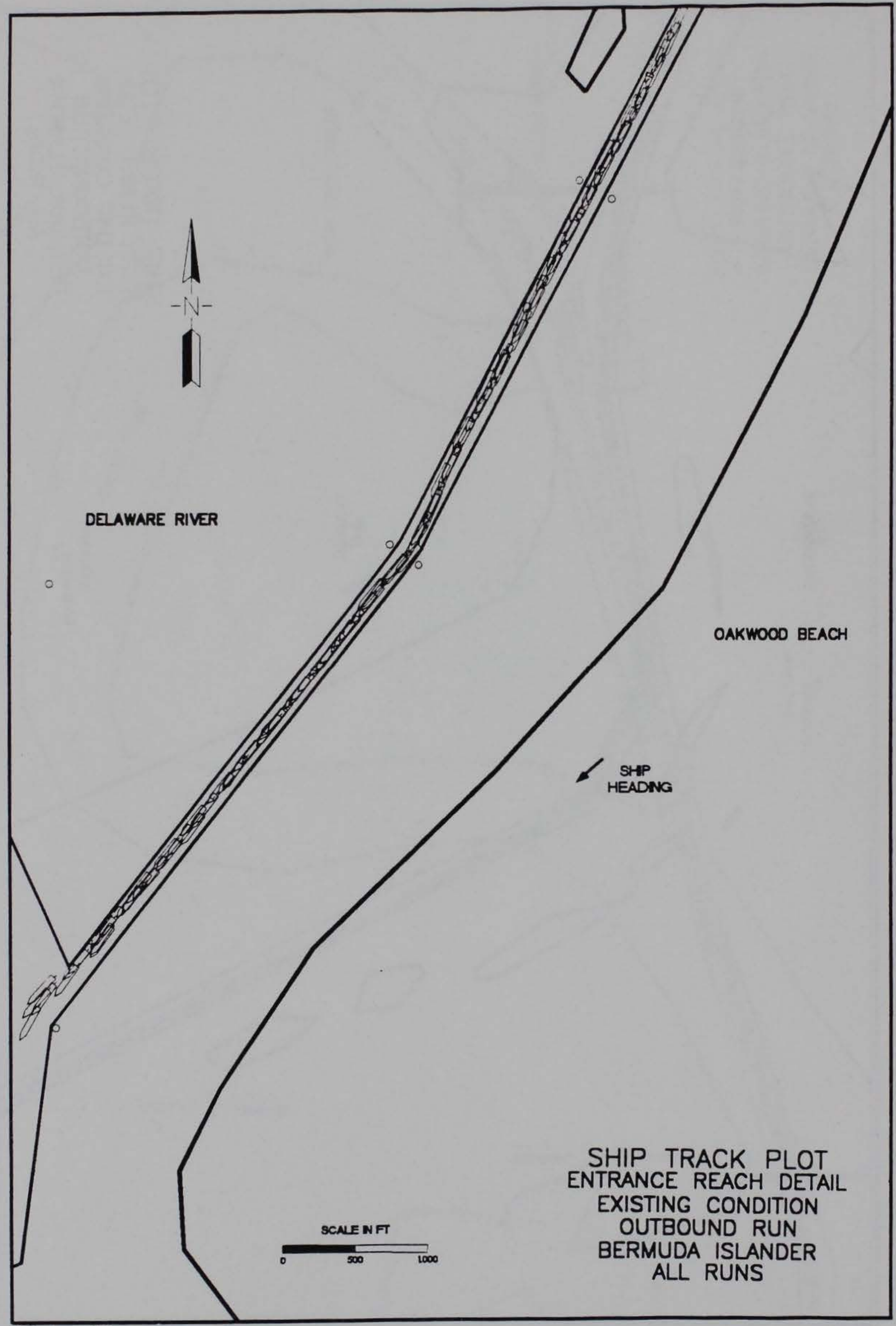

Plate 12 


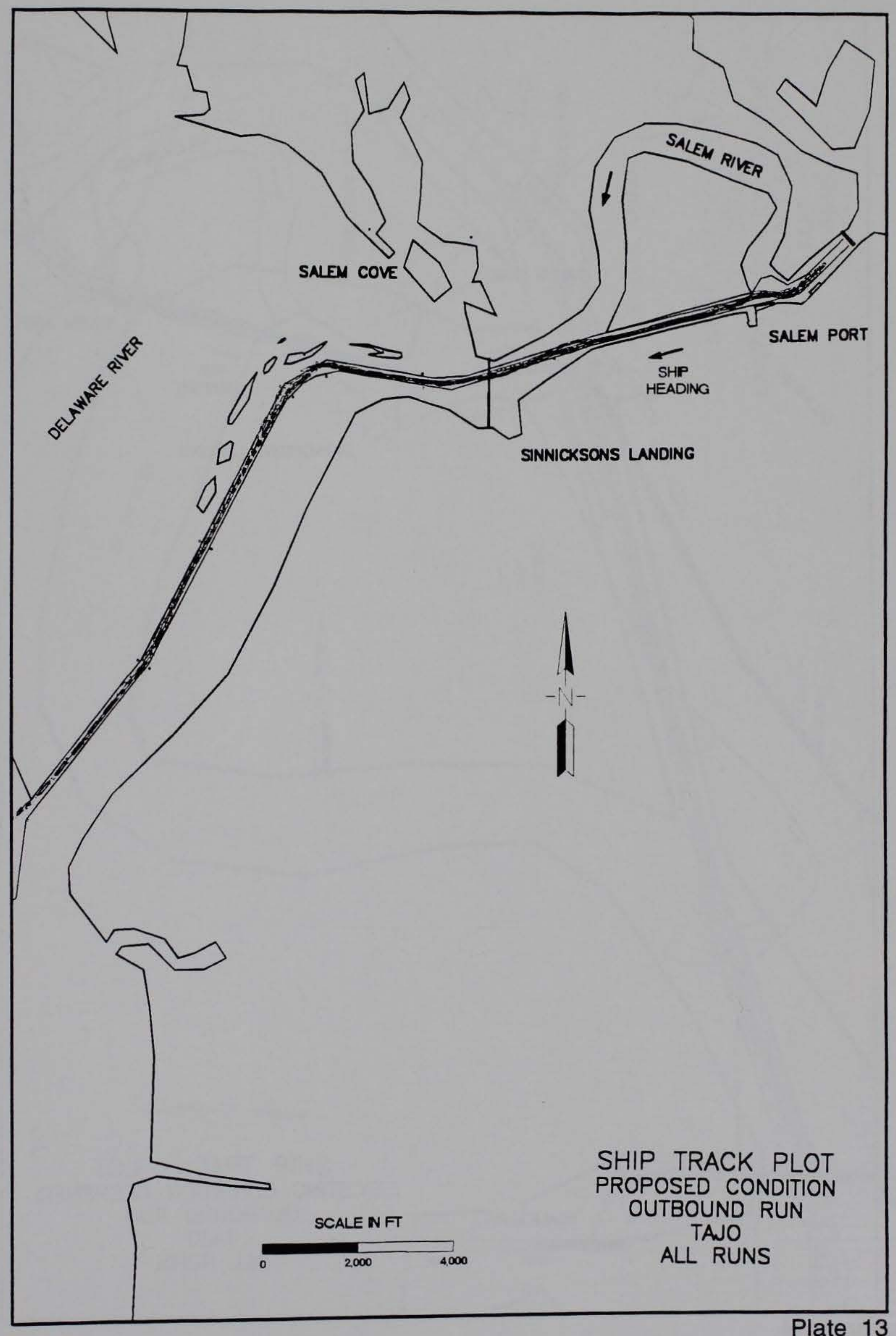




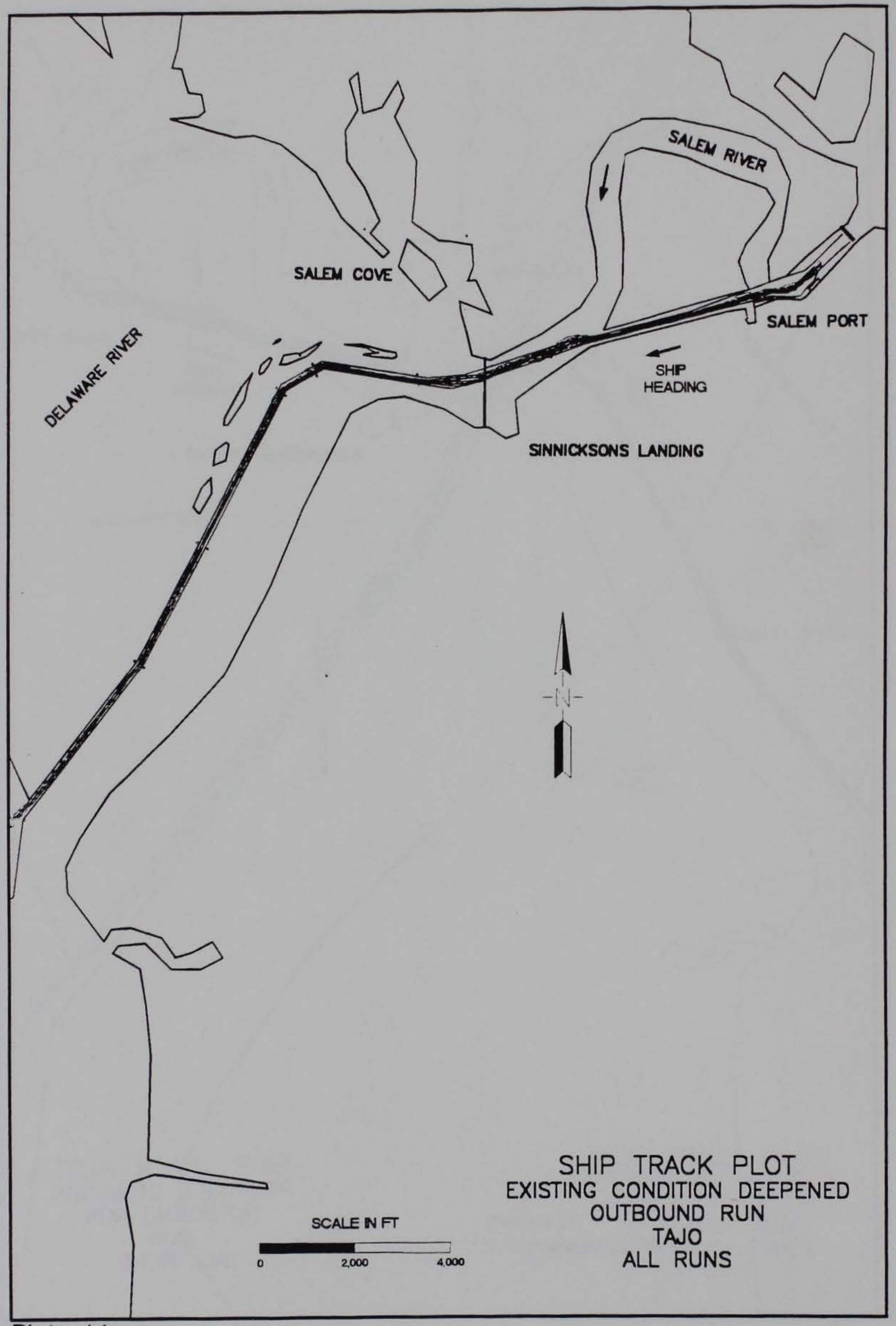

Plate 14 


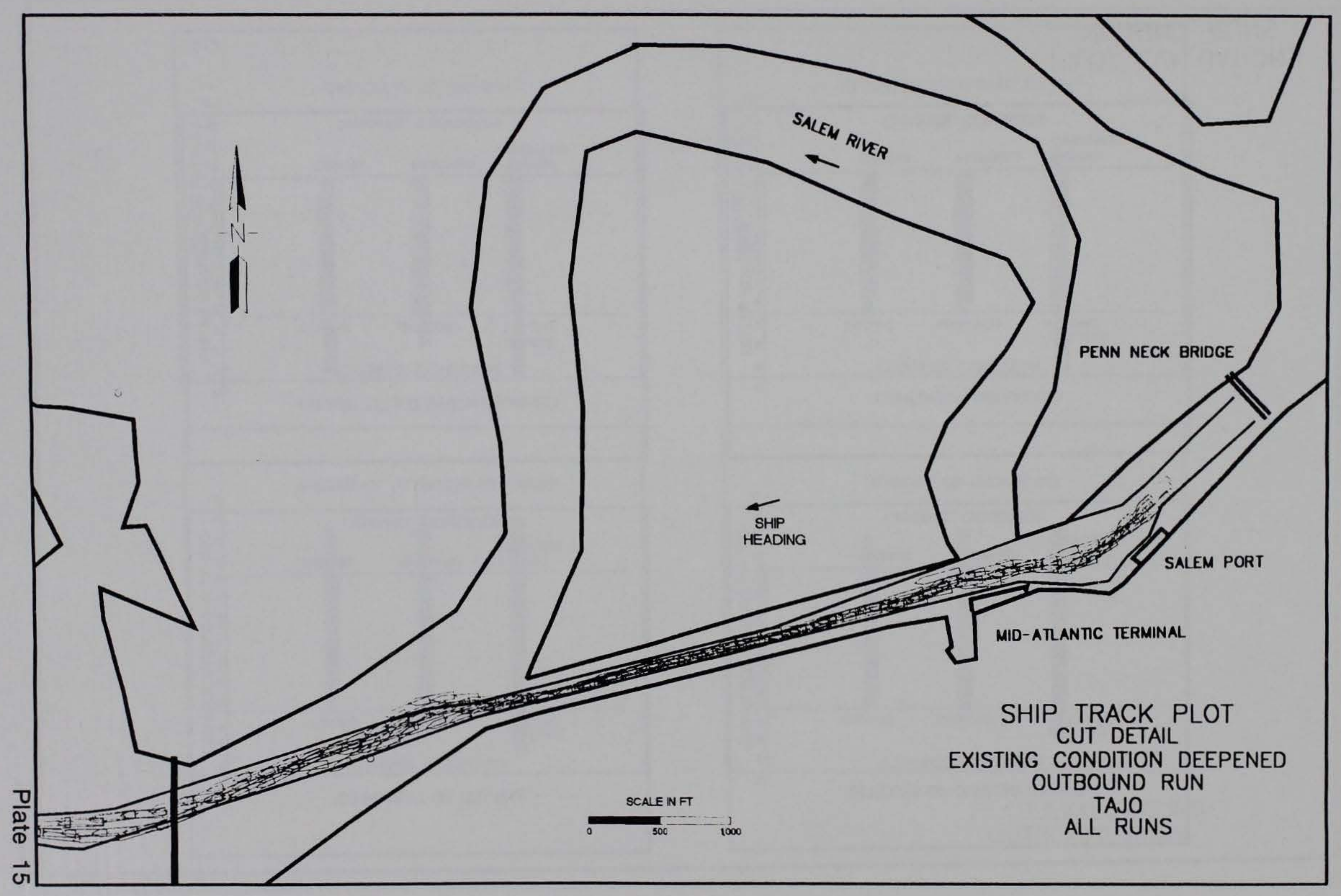




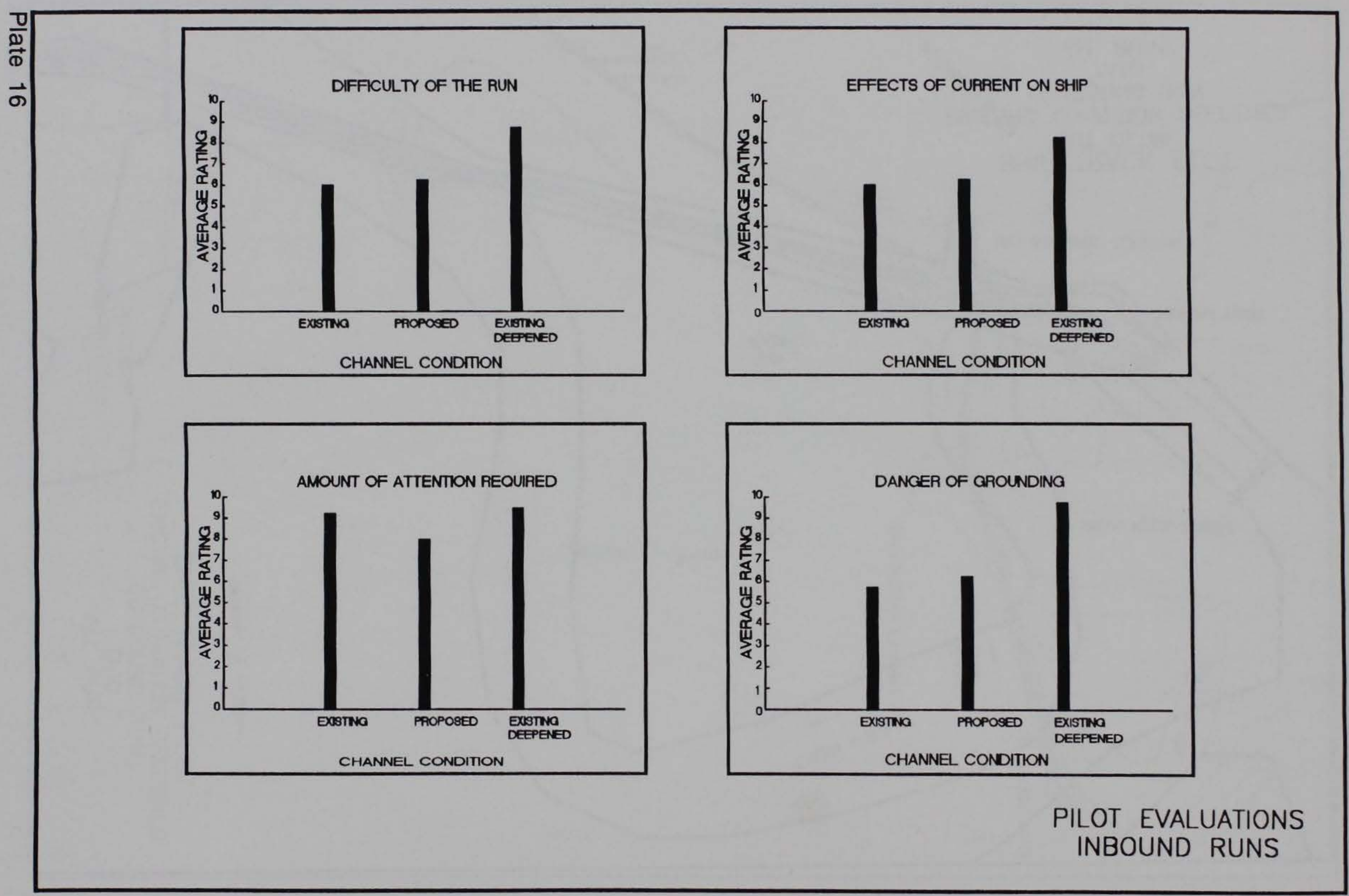




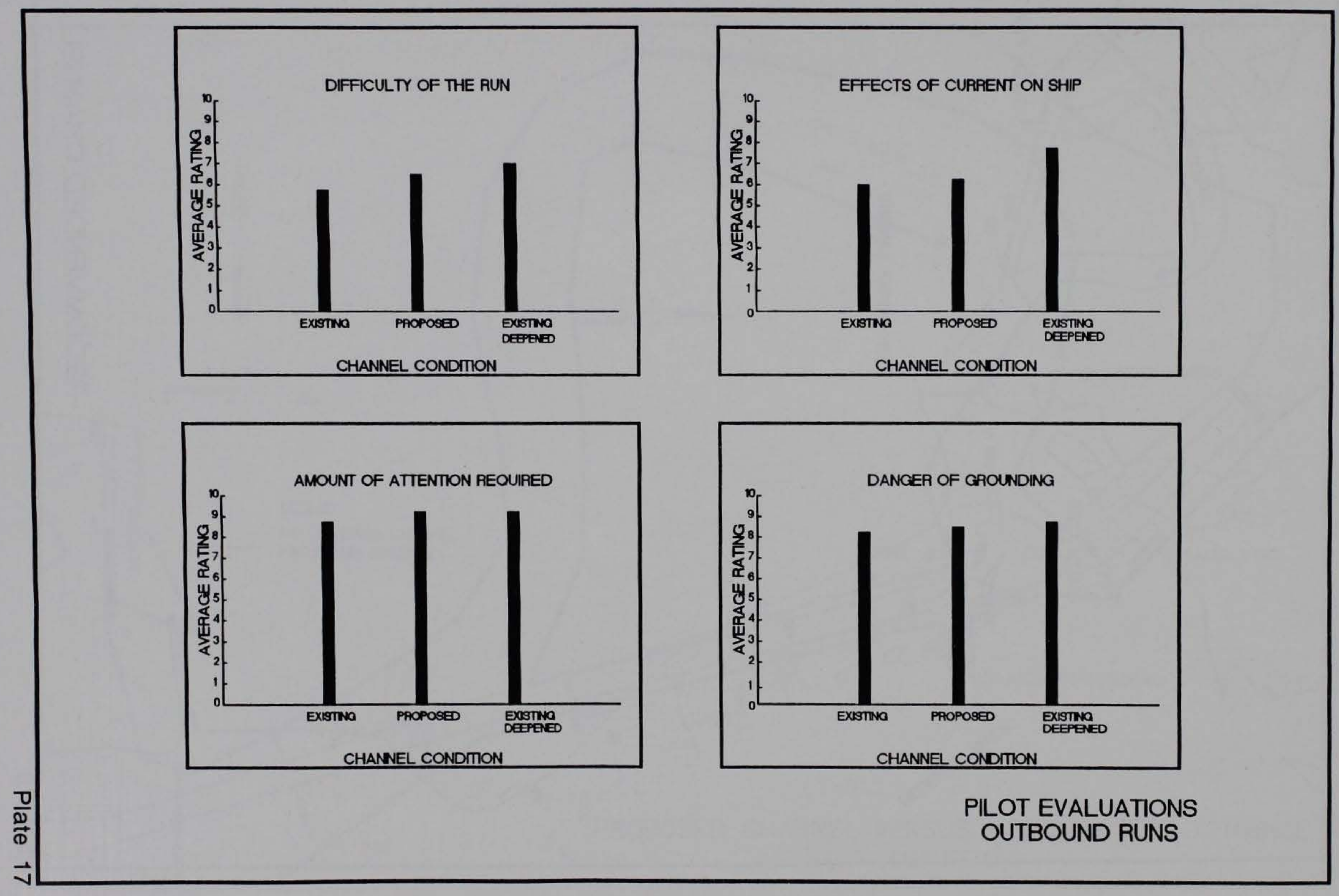




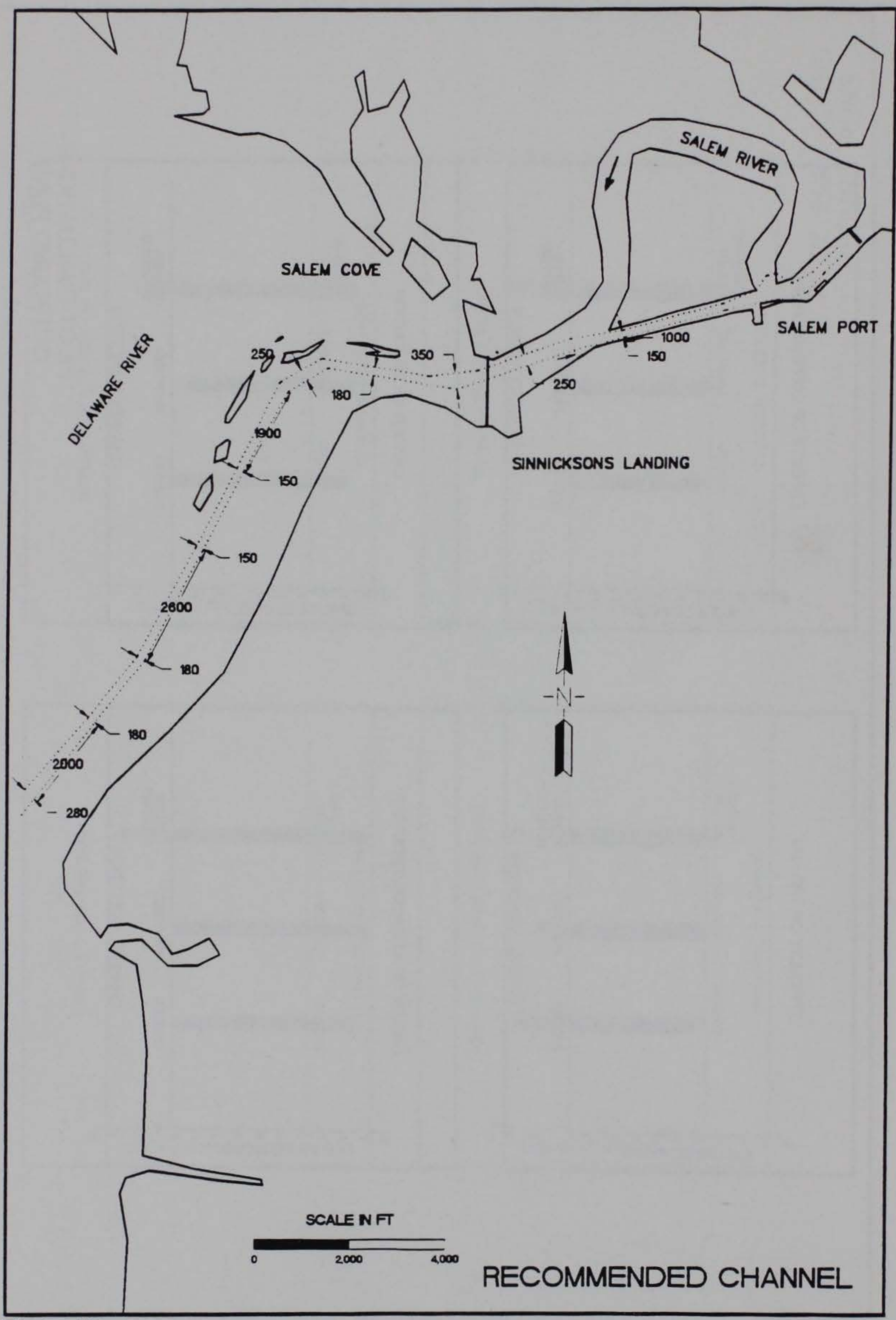

Plate 18 


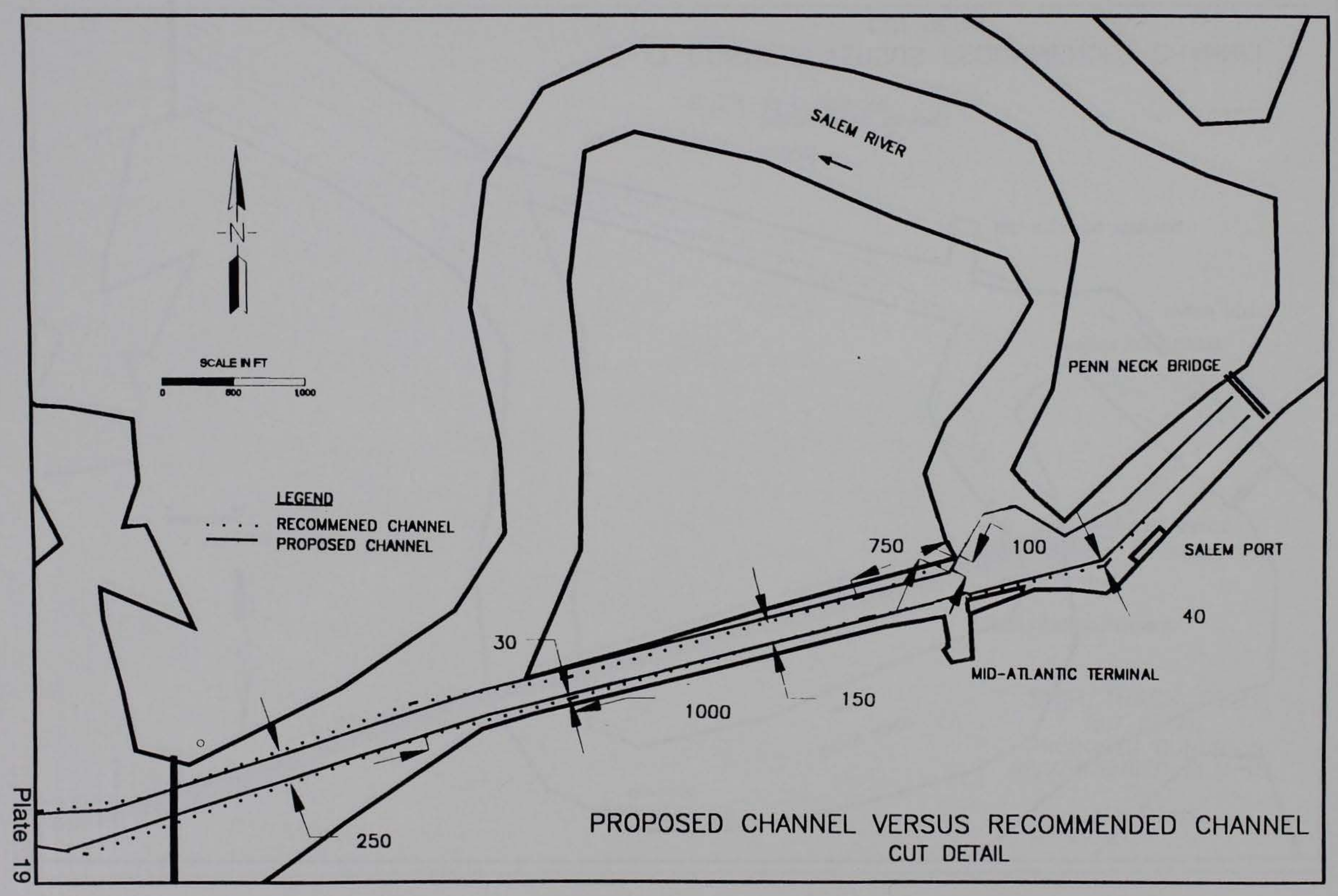




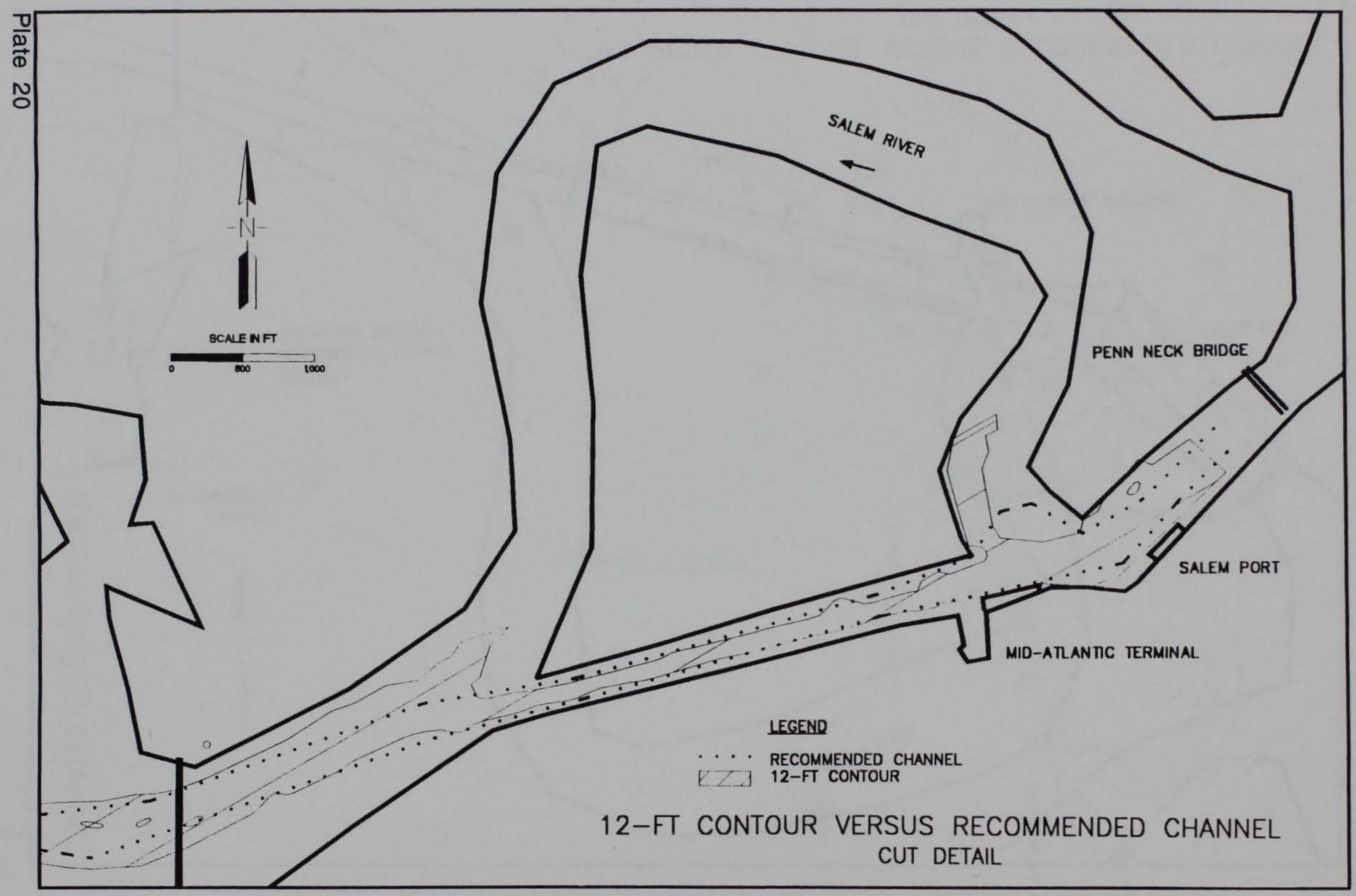




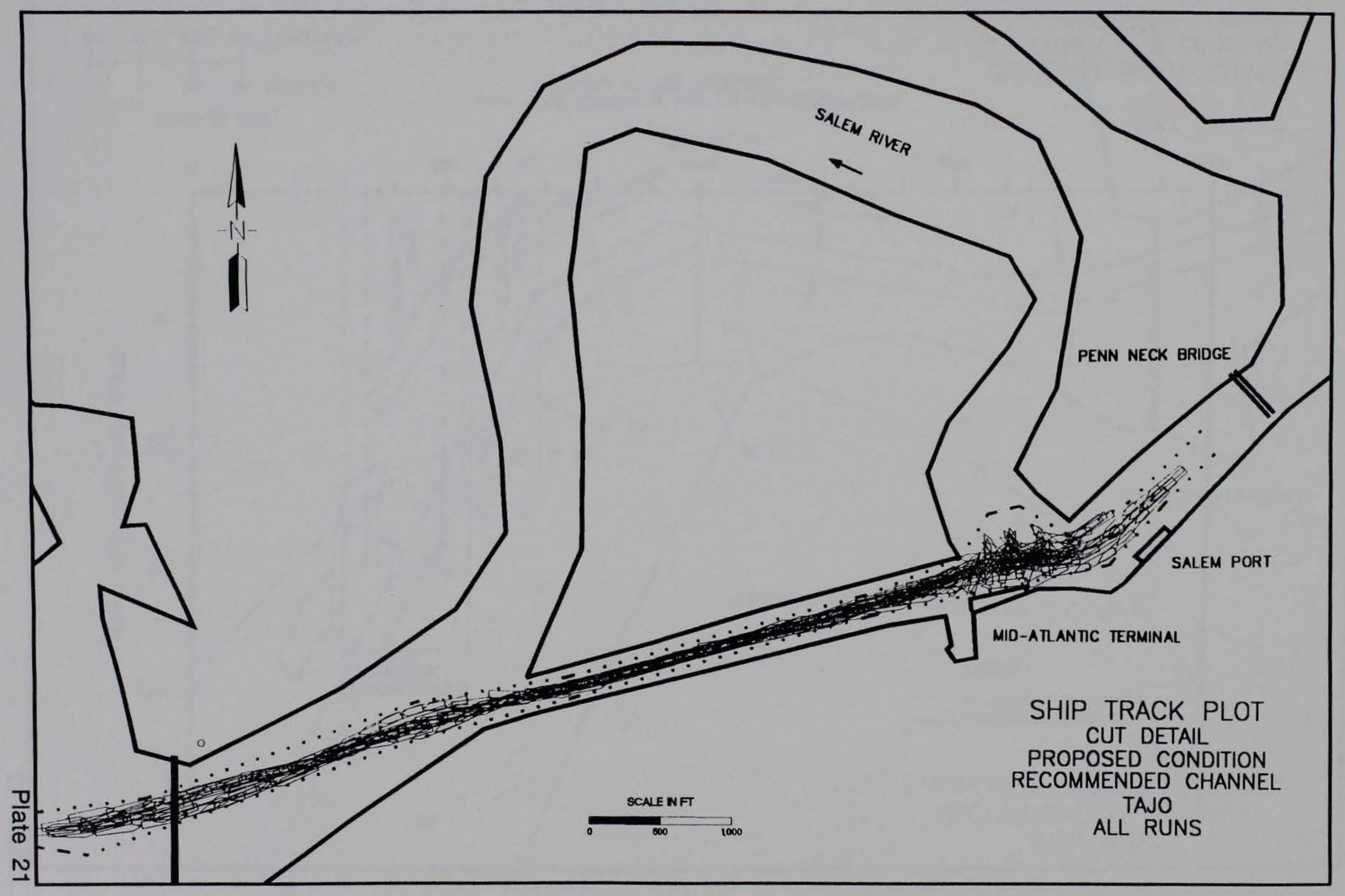




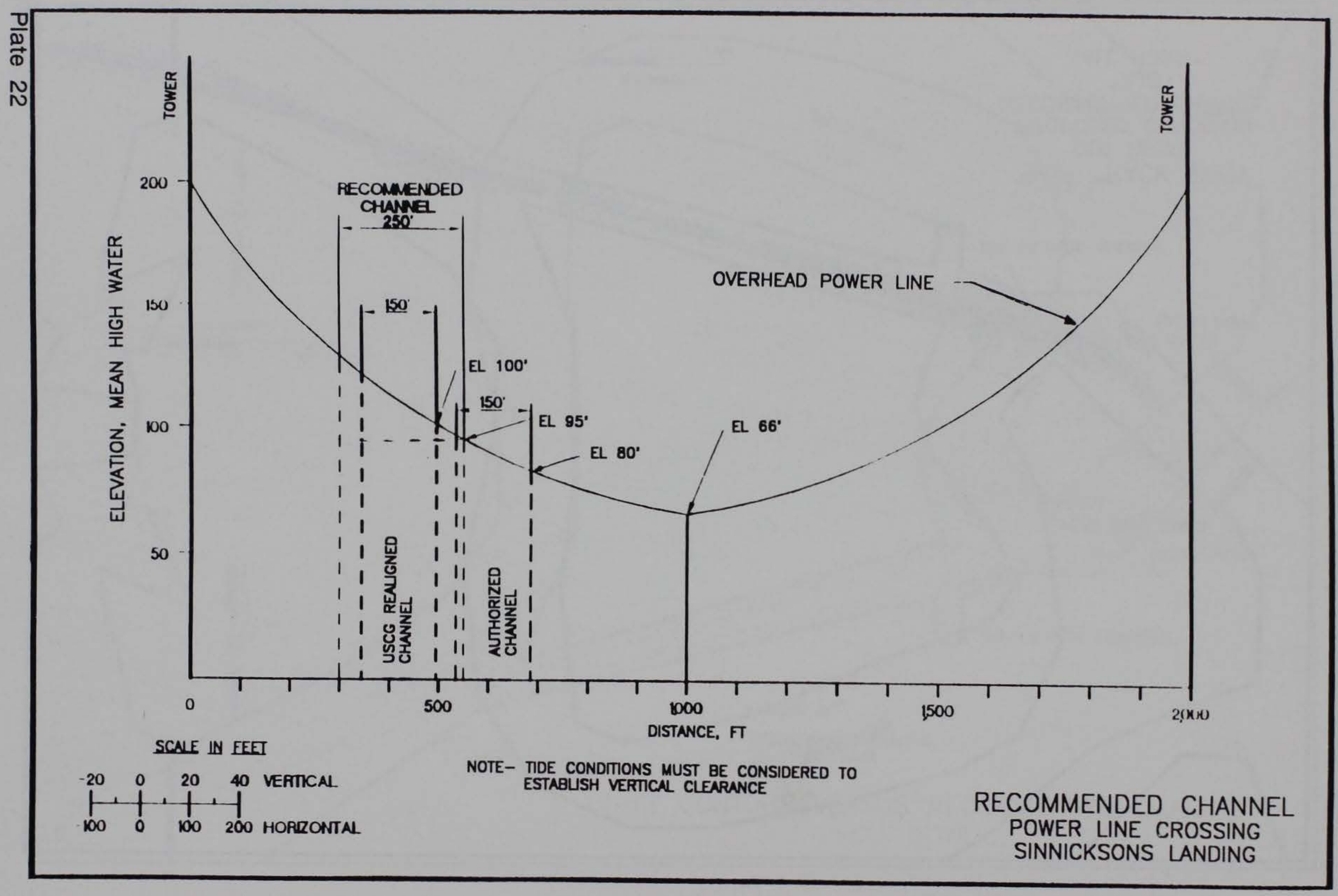




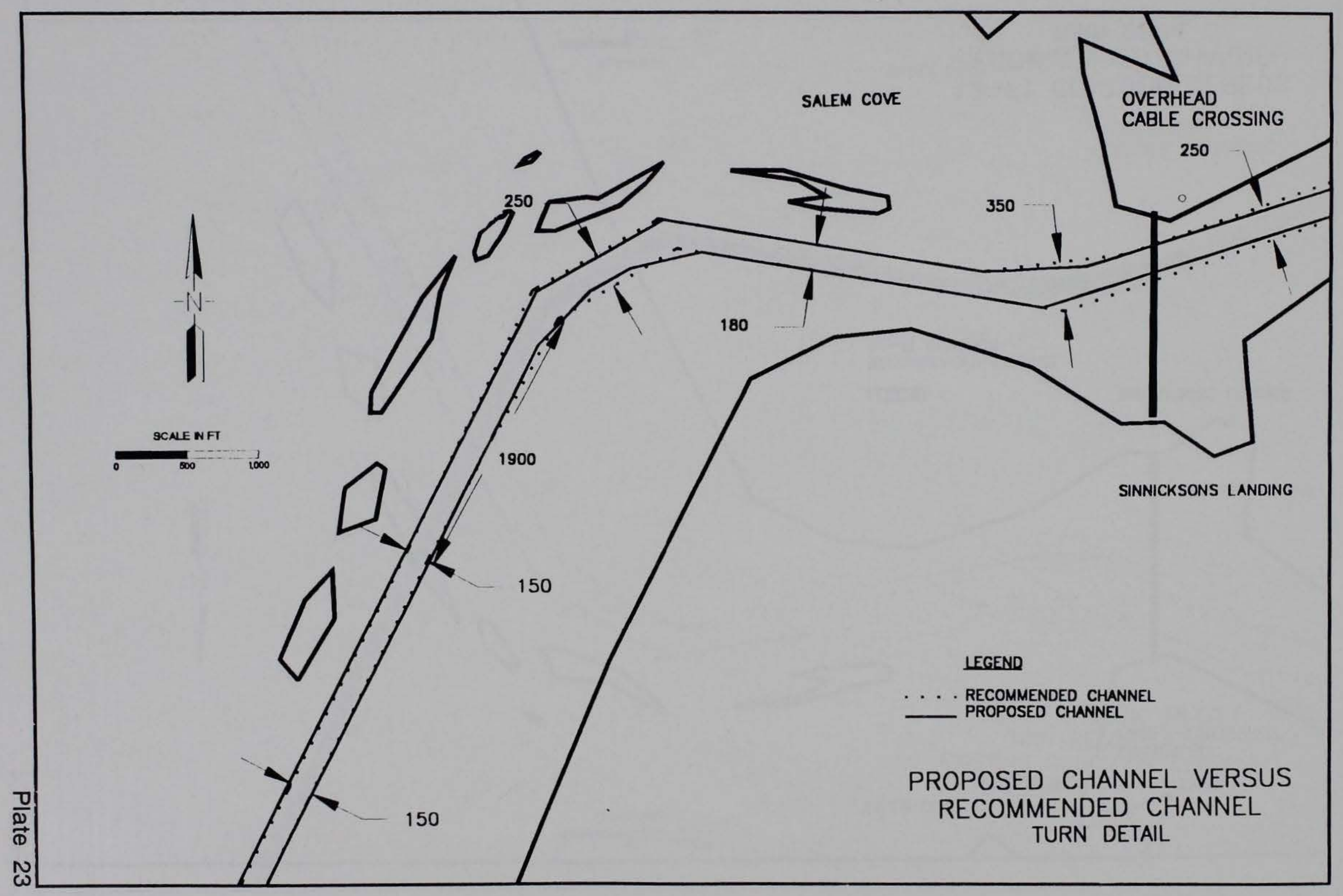




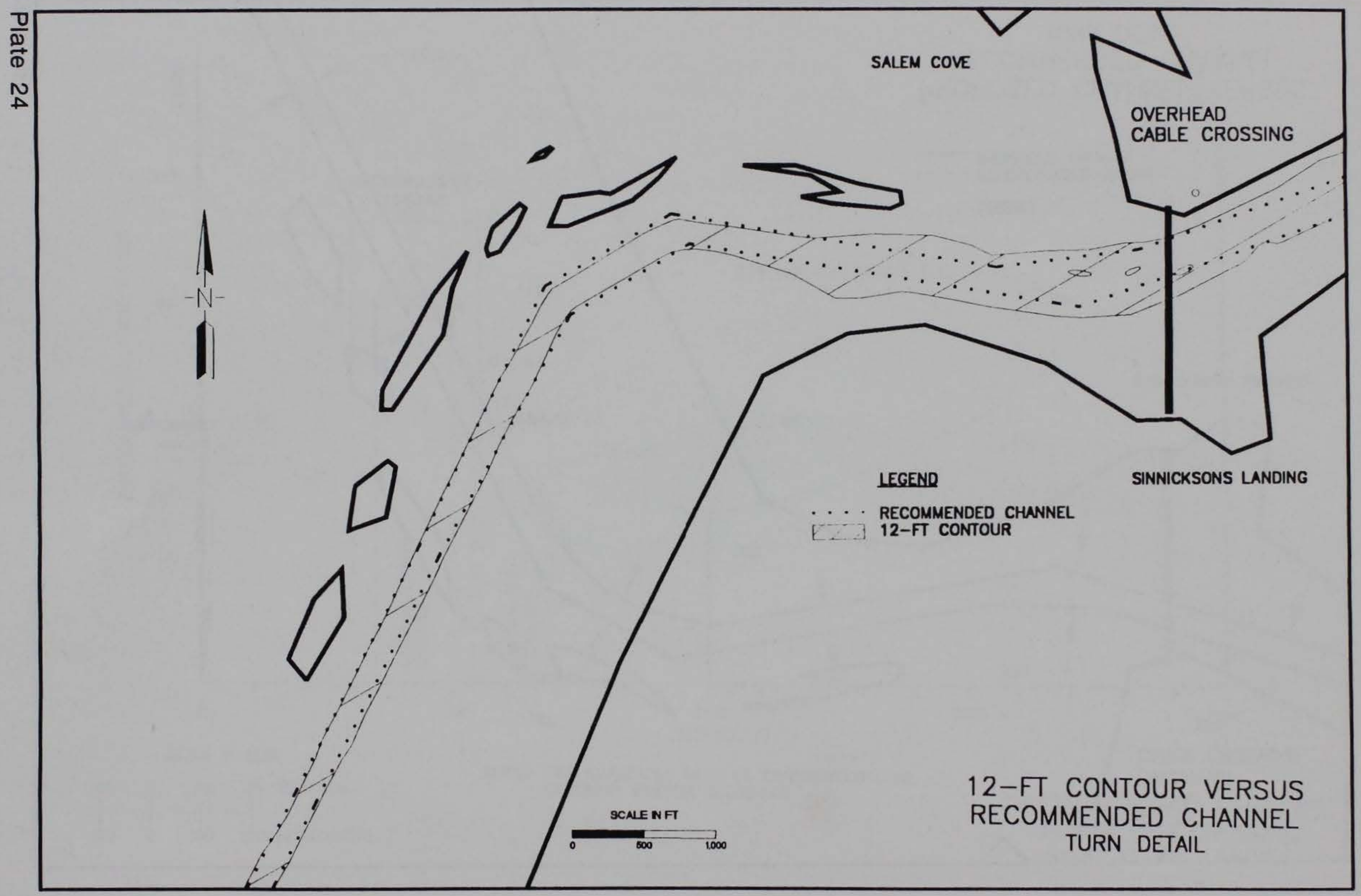




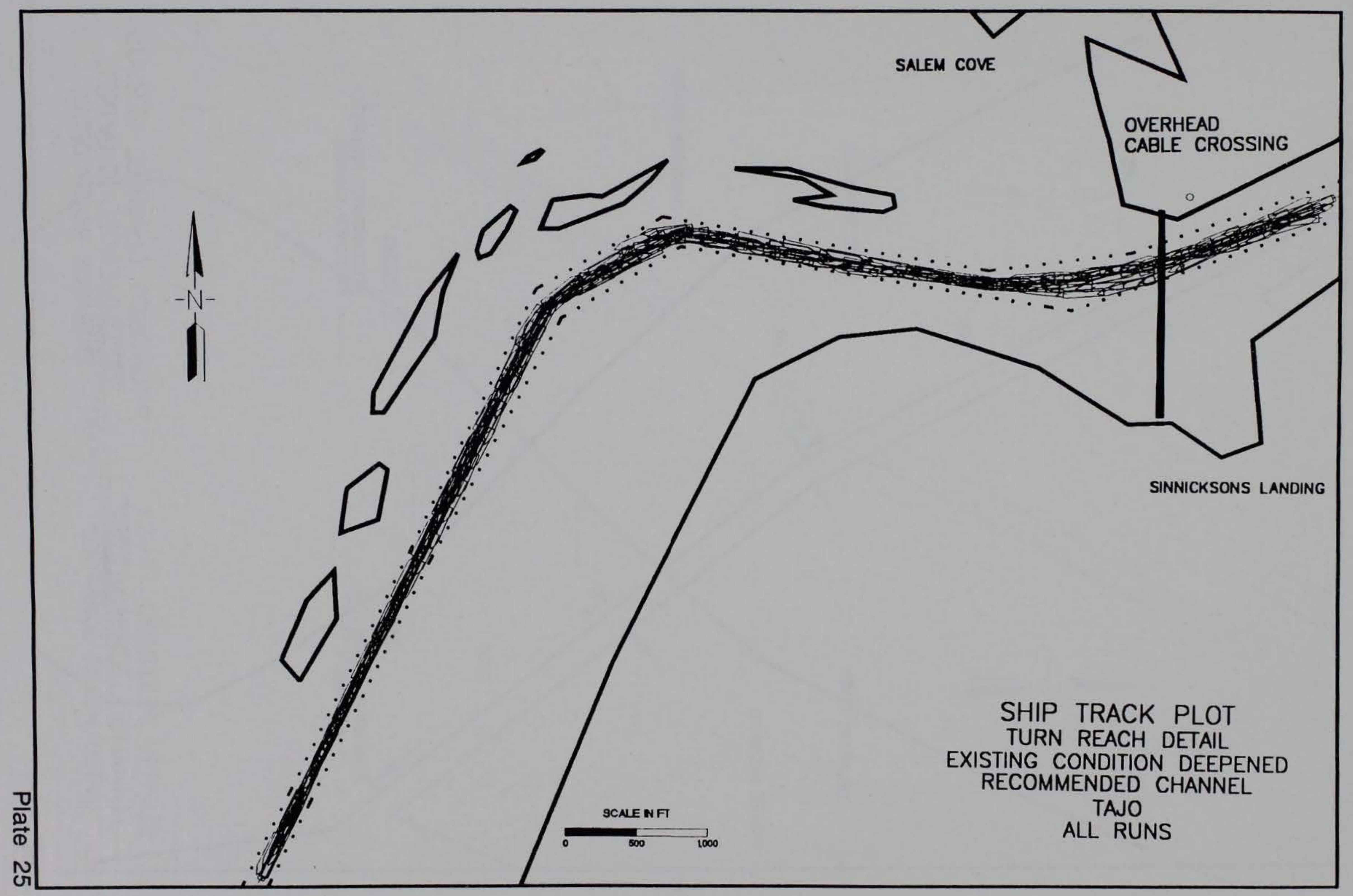




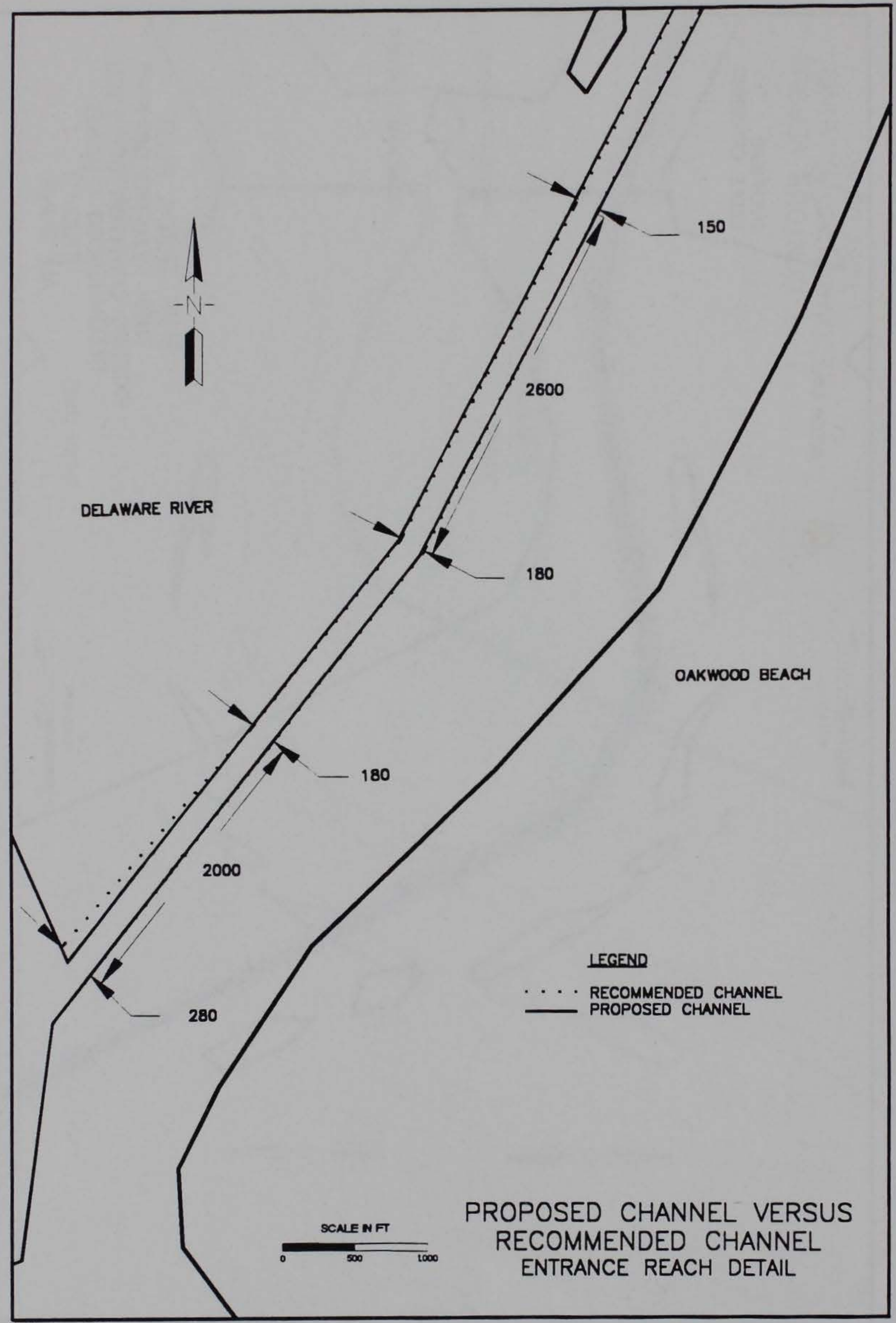

Plate 26 


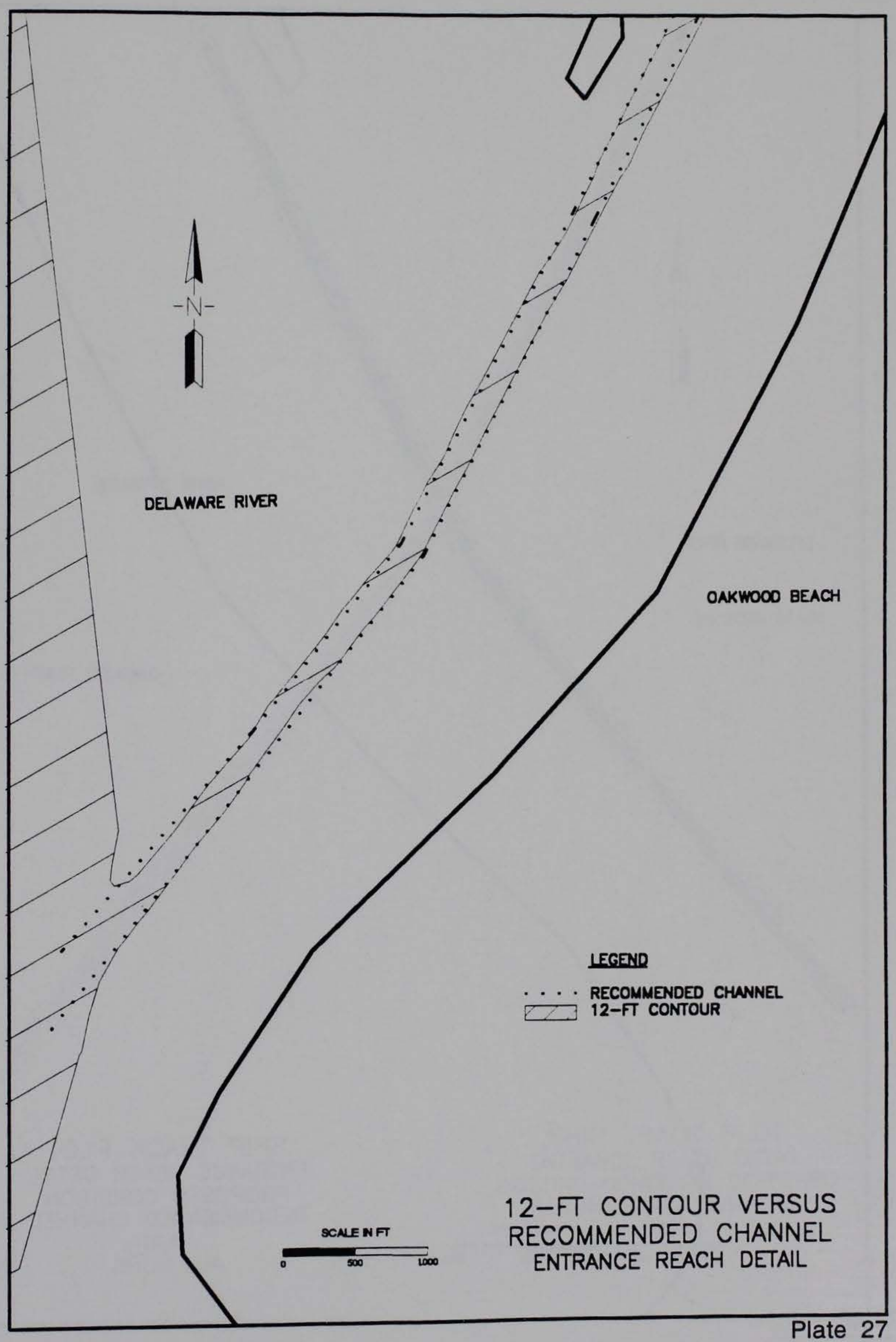




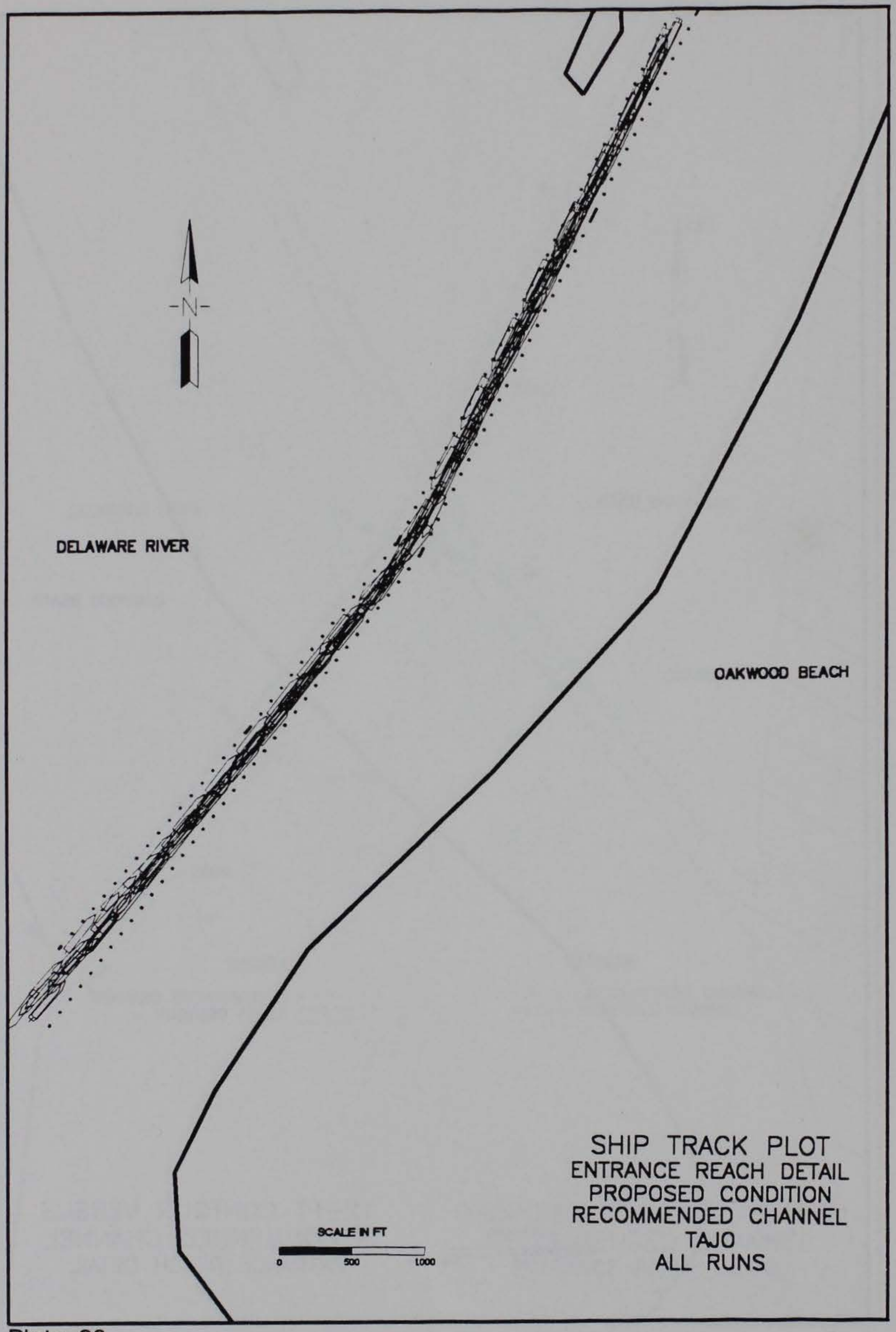

Plate 28 


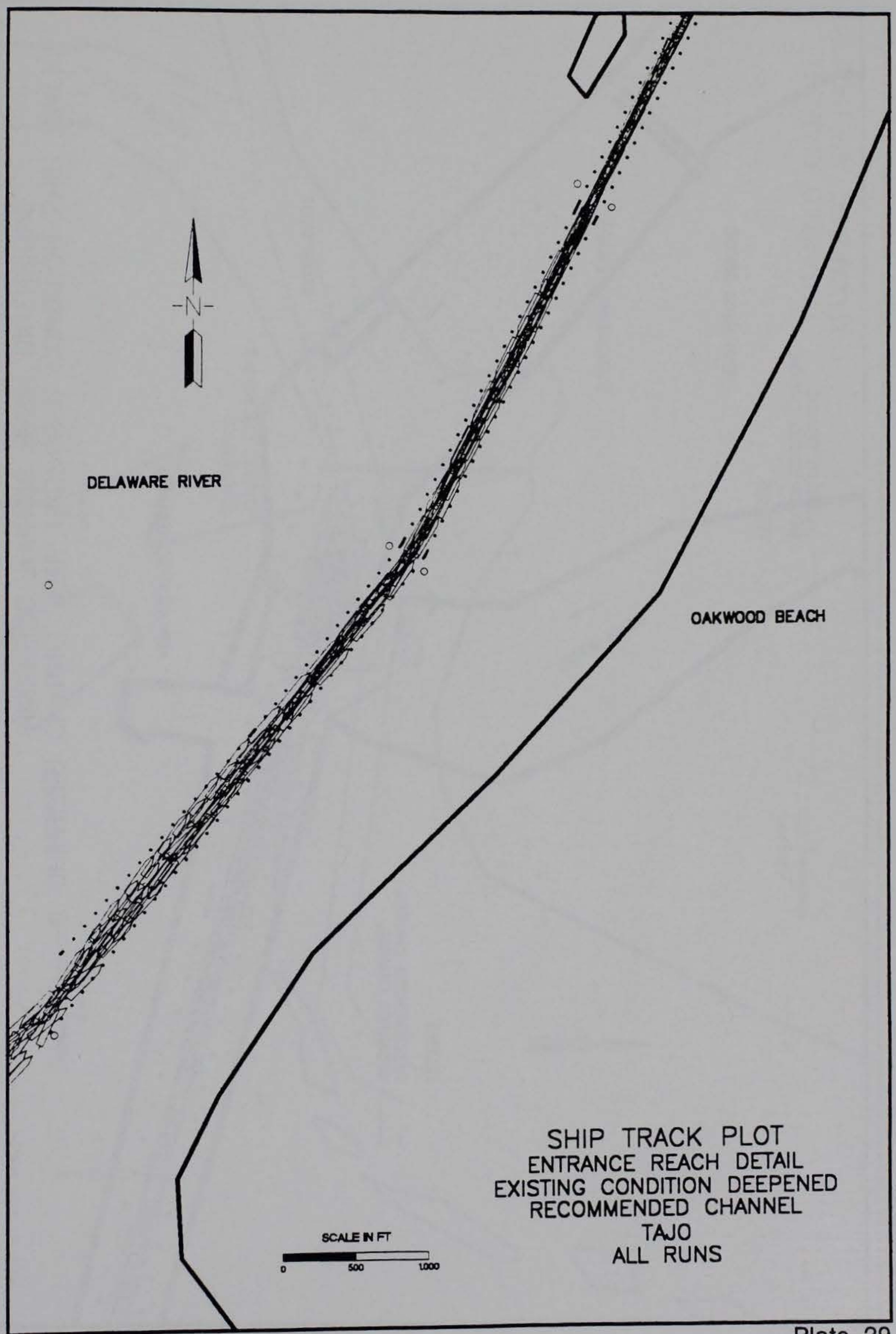




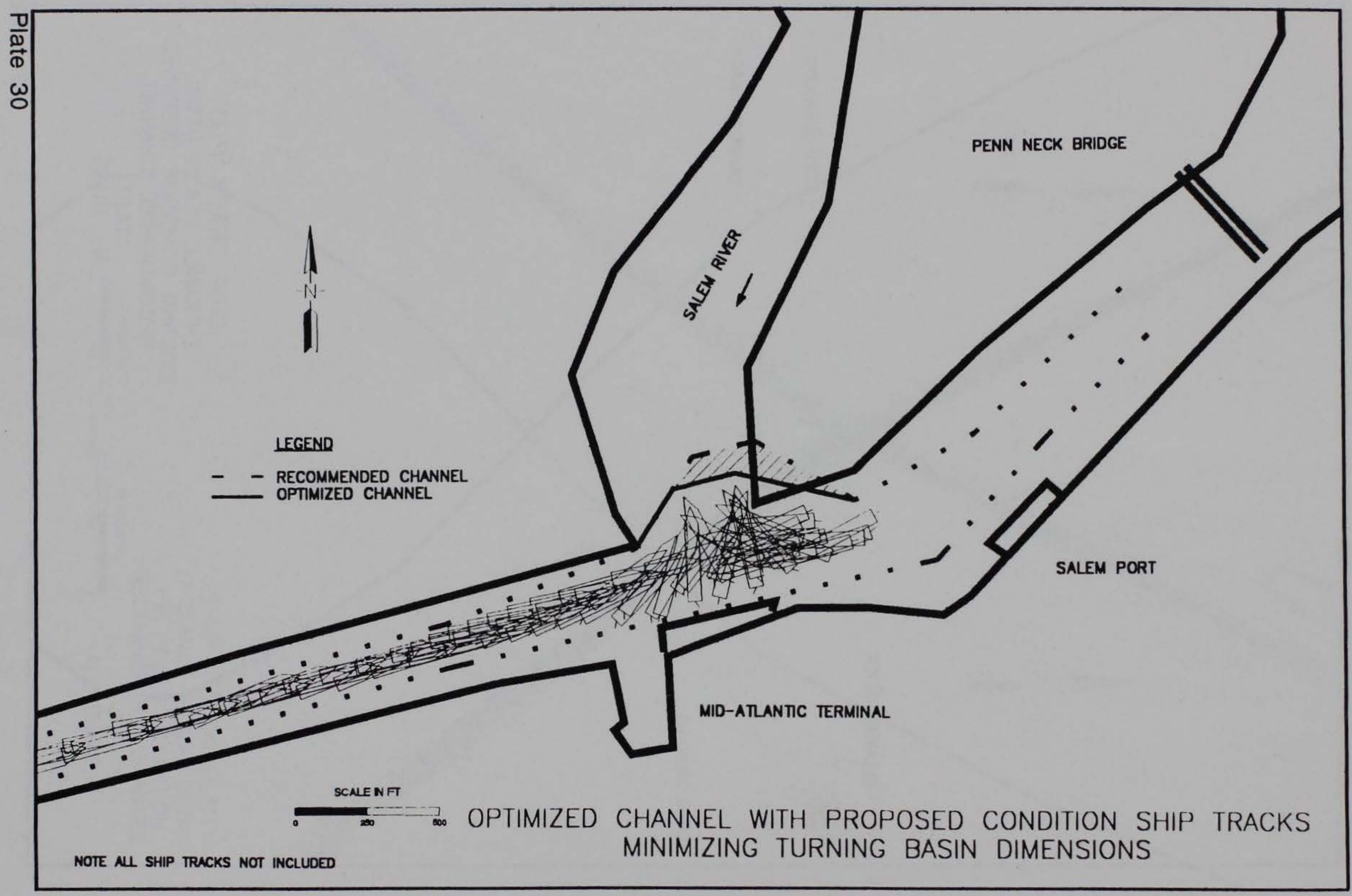




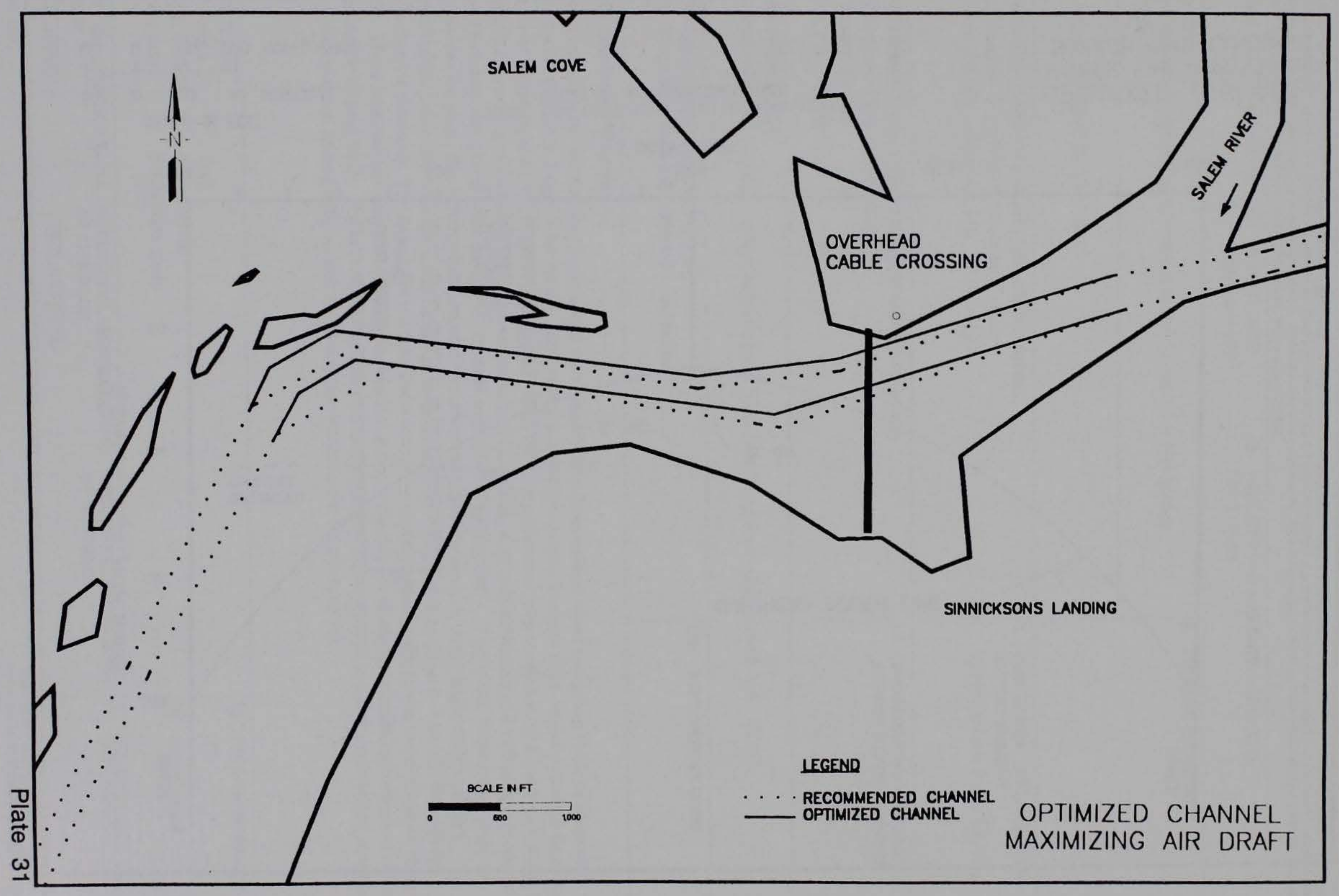




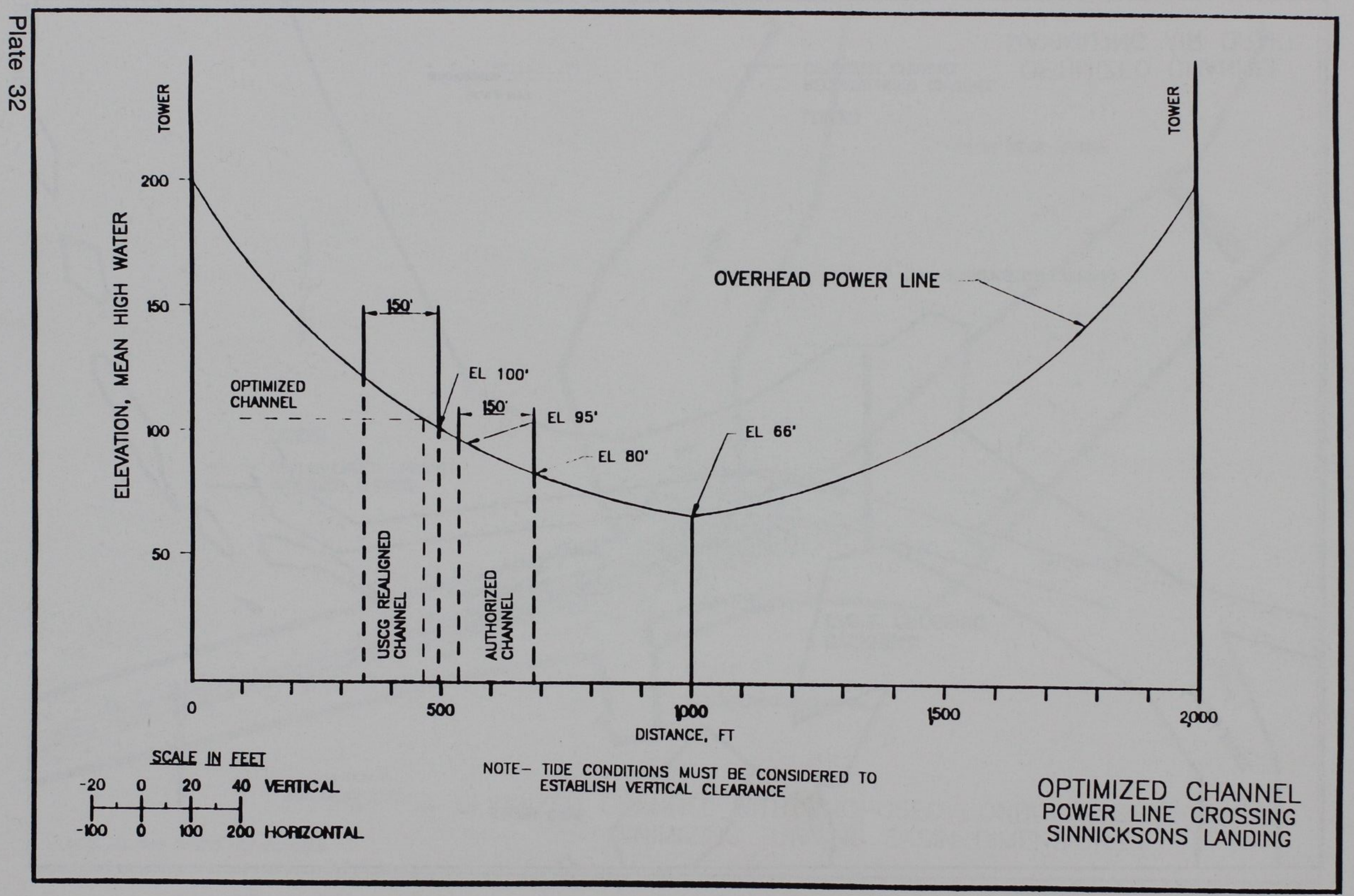




\section{REPORT DOCUMENTATION PAGE}

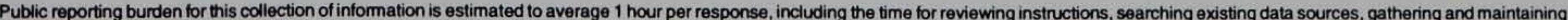

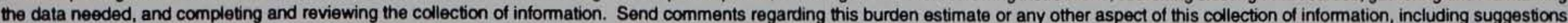

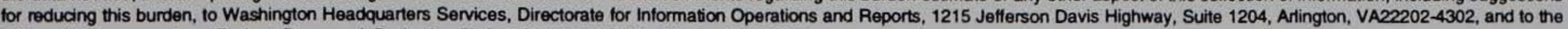
Otfice of Management and Budget, Paperwork Reduction Project (0704-0188), Washington, DC20503.
1. AGENCY USE ONLY (Leave blank)
2. REPORT DATE September 1995
3. REPORT TYPE AND DATES COVERED Final report

4. TITLE AND SUBTITLE

Navigation Study of Proposed Improvements to the Salem River Navigation

Channel, New Jersey

6.AUTHOR(S)

Larry L. Daggett, Michelle M. Thevenot

7. PERFORMING ORGANIZATION NAME(S) AND ADDRESS(ES)

U.S. Army Engineer Waterways Experiment Station

8. PERFORMING ORGANIZATION REPORT NUMBER

3909 Halls Ferry Road, Vicksburg, MS 39180-6199

Miscellaneous Paper HL-95-5

9. SPONSORING/MONITORING AGENCY NAME(S) AND ADDRESS(ES)

U.S. Army Engineer District, Philadelphia

5. FUNDING NUMBERS

2nd and Chestnut Streets

Philadelphia, PA 19106-2991

11. SUPPLEMENTARY NOTES

Available from National Technical Information Service, 5285 Port Royal Road, Springfield, VA 22161.

12a. DISTRIBUTIONAVAILABILITY STATEMENT

12b. DISTRIBUTION CODE

Approved for public release; distribution is unlimited.

10. SPONSORING/MONITORING AGENCY REPORT NUMBER

\section{ABSTRACT (Maximum 200 words)}

This report presents the results, conclusions, and recommendations from a radar-based navigation study of proposed improvements for the Salem River, New Jersey. The present Salem River project consists of an entrance channel from the Delaware River to the Penn's Neck Highway Bridge for Route 49. The authorized project depth is $12 \mathrm{ft}$ mean low water with a width of $150 \mathrm{ft}$ narrowing to $100 \mathrm{ft}$ at the cutoff at Sinnicksons Landing. A project deepening and widening is proposed to provide an 18-ft-deep and 180 - $\mathrm{ft}$-wide navigation channel with a $495-\mathrm{ft}$ turning basin. This would allow larger ships to economically use the port. The existing and proposed plans were modeled on the U.S. Army Engineer Waterways Experiment Station's ship/tow simulator, and locally licensed pilots performed real-time simulated transits through the modeled navigation channels. The data collected from these tests were analyzed and modifications to the proposed design were made. These included tapering the channel in several locations, widening the channel at critical locations, and widening and reshaping the turning basin. It was further recommended that additional improvements to the channel design could be obtained with additional testing with normal visual displays available for the pilots to use.

14. SUBJECT TERMS

Channel design

Navigation channel

New Jersey port
Port

Salem River

Simulation study
15. NUMBER OF PAGES

62

16. PRICE CODE

\begin{tabular}{l|l|l|l|l} 
17. SECURITY CLASSIFICATION & $\begin{array}{l}\text { 18. } \\
\text { OF REPORT } \\
\text { UNCLASSIFIED }\end{array}$ & $\begin{array}{l}\text { SECURITY CLASSIFICATION } \\
\text { OF THIS PAGE } \\
\text { UNCLASSIFIED }\end{array}$ & $\begin{array}{l}\text { SE. SECURITY CLASSIFICATION } \\
\text { OF ABSTRACT }\end{array}$ \\
\hline
\end{tabular}

20. LIMITATION OF ABSTRACT

Standard Form 298 (Rev. 2-89)

NSN 7540-01-280-5500 